ARTICLES

\title{
Proterozoic Tectonostratigraphy and Paleogeography of Central Madagascar Derived from Detrital Zircon U-Pb Age Populations
}

\author{
Rónadh Cox, ${ }^{1}$ Drew S. Coleman, ${ }^{2}$ Carla B. Chokel, Stephen B. DeOreo, \\ Joseph L. Wooden, ${ }^{3}$ Alan S. Collins, ${ }^{4}$ Bert De Waele, ${ }^{5}$ and Alfred Kröner ${ }^{6}$ \\ Department of Geosciences, Williams College, Williamstown, Massachusetts 01267, U.S.A. \\ (e-mail: rcox@williams.edu)
}

\begin{abstract}
A B S T R A C T
Detrital zircon U-Pb ages determined by SHRIMP distinguish two clastic sequences among Proterozoic metasedimentary rocks from central Madagascar. The Itremo Group is older: zircon data, stromatolite characteristics, and carbon isotope data all point to a depositional age around 1500-1700 Ma. The Molo Group is younger, deposited between $\sim 620 \mathrm{Ma}$ (the age of the youngest zircon) and $560 \mathrm{Ma}$ (the age of metamorphic overgrowths on detrital cores). Geochronologic provenance analysis of the Itremo Group points to sources in East Africa as well as local sources in central and southern Madagascar but provides no evidence for a detrital contribution from northern and eastern Madagascar nor from southern India. Detrital zircon and sedimentologic similarities between rocks of the Itremo Group and the Zambian Muva Supergroup suggest a lithostratigraphic correlation between the two. The Molo Group has a strong 1000-1100 Ma detrital signature that also indicates an east African provenance and suggests a Neoproterozoic geographic connection with Sri Lanka but shows no indication of input from the Dharwar craton and eastern Madagascar. Central Madagascar was probably juxtaposed with the Tanzanian craton in the Paleo- and Mesoproterozoic, whereas northern and eastern Madagascar were connected to India. Internal assembly of Madagascar postdates Neoproterozoic Molo Group sedimentation and is likely to have occurred at about $560 \mathrm{Ma}$.
\end{abstract}

Online enhancements: appendix, table.

\section{Introduction}

Polydeformed Precambrian rocks of Madagascar record the Neoproterozoic and earliest Phanerozoic assembly of Gondwana, and Madagascar occupies a central position in the East African Orogen (Stern 1994). Consequently, its highly strained and poorly understood basement has been a focus for under-

Manuscript received July 3, 2003; accepted October 23, 2003.

${ }^{1}$ Author for correspondence.

${ }^{2}$ Department of Geological Sciences, University of North Carolina, Chapel Hill, North Carolina 27599-3315, U.S.A.

${ }^{3}$ U.S. Geological Survey, 345 Middlefield Road, Menlo Park, California 94025, U.S.A.

${ }^{4}$ Tectonics Special Research Centre, School of Earth and Geographical Sciences, University of Western Australia, Crawley, Western Australia 6009, Australia.

${ }^{5}$ Tectonics Special Research Centre, Department of Applied Geology, Curtin University of Technology, Perth, Western Australia 6845, Australia.

${ }^{6}$ Institut für Geowissenschaften, Universität Mainz, Mainz 55099, Germany. standing the dynamics of Gondwana amalgamation (Handke et al. 1999; Kröner et al. 2000; Nédélec et al. 2000; Collins and Windley 2002; Collins et al. 2003a). Sorting out paleogeographic affinities is critical, but deconvolving assembled Gondwana into pre-Gondwana continental elements is difficult because the geology is structurally complex and the geochronologic database is small.

Paleogeographic complexity is evident in Madagascar. There are geological and isotopic similarities between Archean crystalline basement rocks of northern Madagascar and the western Dharwar craton of India (Tucker et al. 1999b; Collins et al. 2003c), chemical and geochronologic similarities between Neoproterozoic igneous rocks in central Madagascar and Sri Lanka (Kröner et al. 2000), and midProterozoic source-sediment links between central Madagascar and east Africa (Cox et al. 1998). Pro- 


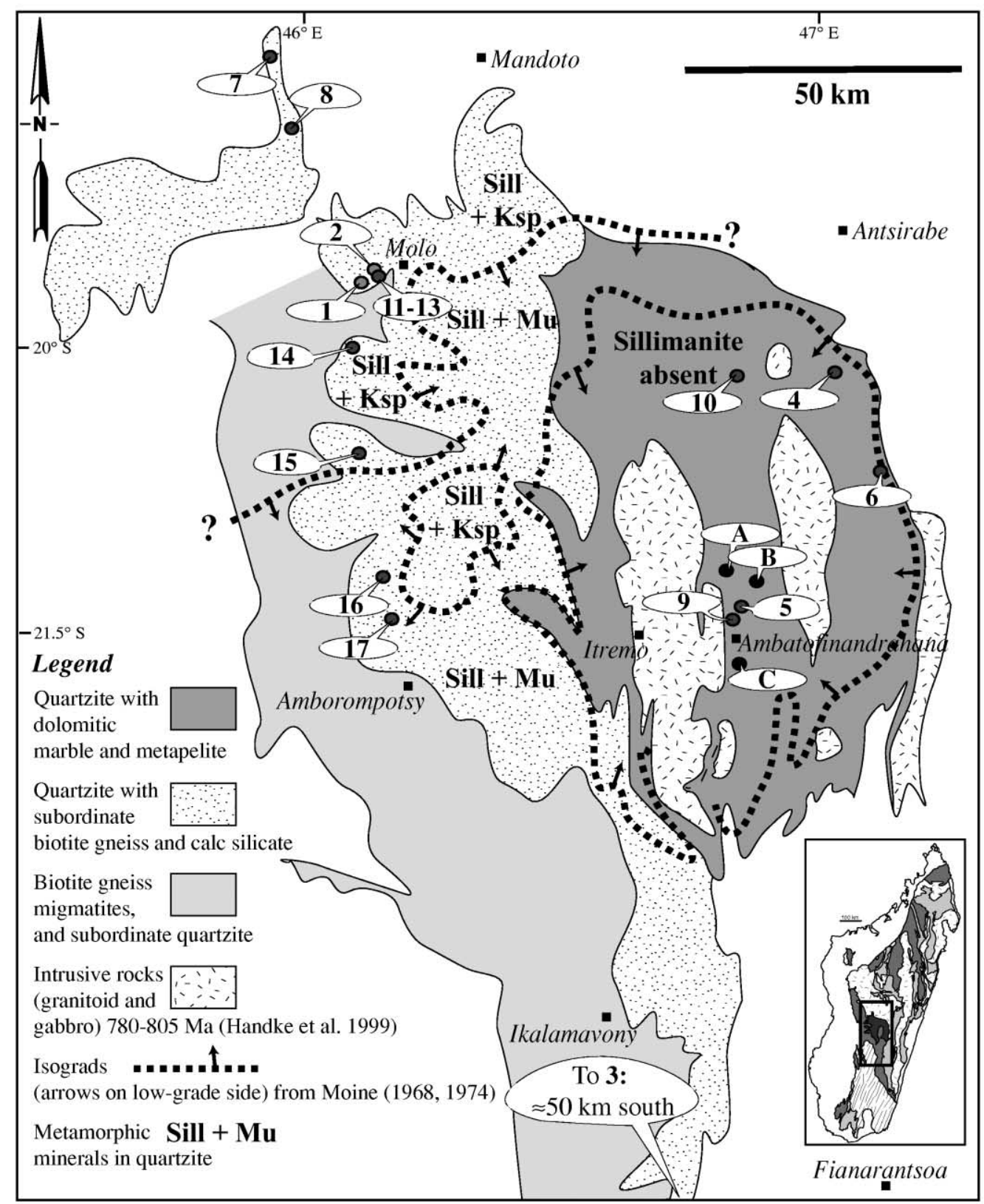

Figure 1. Lithologies of Itremo massif metasedimentary rocks, generalized after Moine (1968, 1974). The stratigraphic boundary between the Itremo and Molo Groups is not indicated because its location is not known, and for simplicity, only major $\mathrm{U}-\mathrm{Pb}$ dated plutons are shown. Encircled numbers and letters represent sample locations and are keyed to sample information and data in tables 1-4. Inset map shows main lithostructural divisions of Madagascar (Cox et al. 1998, their fig. 1), and box represents area of main figure.

posed Neoproterozoic locations for Madagascar with respect to Rodinia include part of an Andean arc adjacent to India on the western edge of Rodinia (Handke et al. 1999; Torsvik et al. 2001); a passive margin of the Tanzanian craton on the eastern edge of Rodinia (Cox et al. 1998), a Seychelles-type microcontinent, unattached to Rodinia (Kröner et al.
2000; Collins and Windley 2002); or in the continental interior of Rodinia (Kröner et al. 2000). In addition, there are equally viable non-Rodinia possibilities, for example, the proposed MadagascarIndia-Somalia-Sri Lanka-Seychelles SLAMIN terrane (Meert 2003).

Metasedimentary rocks in highly deformed areas 
Table 1. Geochronology and Carbon Isotope Sample Lithologies and Locations

\begin{tabular}{|c|c|c|c|c|c|}
\hline \multicolumn{2}{|c|}{ Sample number } & Lithology & Latitude & Longitude & Location \\
\hline \multicolumn{6}{|c|}{ Molo Group: } \\
\hline 1 & MAD 00-4 & Quartzite & $19^{\circ} 55.9^{\prime} \mathrm{S}$ & $46^{\circ} 10.6^{\prime} \mathrm{E}$ & Ampasipotsy Hill, west of Molo village \\
\hline 2 & MAD 00-9 & Bt gneiss & $19^{\circ} 55.6^{\prime} \mathrm{S}$ & $46^{\circ} 10.2^{\prime} \mathrm{E}$ & Ampasipotsy Hill, west of Molo village \\
\hline 3 & Collins 32/98 & $\mathrm{Hb}-\mathrm{Px}$ psammite & $21^{\circ} 57.7^{\prime} \mathrm{S}$ & $46^{\circ} 34.9^{\prime} \mathrm{E}$ & Mafaitra Quarry, west of Ankaramena \\
\hline \multicolumn{6}{|c|}{ Itremo Group: } \\
\hline 4 & MAD 93-113 & Quartzite & $20^{\circ} 03.8^{\prime} \mathrm{S}$ & $46^{\circ} 59.8^{\prime} \mathrm{E}$ & Kiboy Hill, west of Ibity \\
\hline 5 & MAD 93-125 & Quartzite & $20^{\circ} 30.3^{\prime} \mathrm{S}$ & $46^{\circ} 49.7^{\prime} \mathrm{E}$ & $\begin{array}{l}\text { Saronara Mountain, north of } \\
\text { Ambatofinandrahana }\end{array}$ \\
\hline 6 & MAD 93-169 & Quartzite & $20^{\circ} 14.5^{\prime} \mathrm{S}$ & $47^{\circ} 03.1^{\prime} \mathrm{E}$ & Somadex Mine, south of Ibity \\
\hline 7 & MAD 95-24 & Quartzite & $19^{\circ} 37.8^{\prime} \mathrm{S}$ & $45^{\circ} 59.2^{\prime} \mathrm{E}$ & $\begin{array}{l}\text { Antsirabe-Miandrivazo Road, west of } \\
\text { Mandoto }\end{array}$ \\
\hline 8 & MAD 97-1 & Quartzite & $19^{\circ} 38.5^{\prime} \mathrm{S}$ & $46^{\circ} 01.3^{\prime} \mathrm{E}$ & $\begin{array}{l}\text { Bevitsika Ridge, south of Miandrivazo- } \\
\text { Antsirabe road }\end{array}$ \\
\hline 9 & MAD 97-13 & Quartzite & $20^{\circ} 30.4^{\prime} \mathrm{S}$ & $46^{\circ} 49.7^{\prime} \mathrm{E}$ & $\begin{array}{l}\text { Saronara Mountain, north of } \\
\text { Ambatofinandrahana }\end{array}$ \\
\hline 10 & MAD 97-22 & Quartzite & $20^{\circ} 01.2^{\prime} \mathrm{S}$ & $46^{\circ} 49.3^{\prime} \mathrm{E}$ & Belanitra area, west of Vatolahy \\
\hline 11 & MAD 00-5 & Quartzite & $19^{\circ} 55.8^{\prime} \mathrm{S}$ & $46^{\circ} 10.2^{\prime} \mathrm{E}$ & Ampasipotsy Hill, west of Molo village \\
\hline 12 & MAD 00-6 & Quartzite & $19^{\circ} 55.8^{\prime} \mathrm{S}$ & $46^{\circ} 10.2^{\prime} \mathrm{E}$ & Ampasipotsy Hill, west of Molo village \\
\hline 13 & MAD 00-8 & Quartzite & $19^{\circ} 55.6^{\prime} \mathrm{S}$ & $46^{\circ} 10.2^{\prime} \mathrm{E}$ & Ampasipotsy Hill, west of Molo village \\
\hline 14 & MAD 00-11 & Quartzite & $20^{\circ} 04.1^{\prime} \mathrm{S}$ & $46^{\circ} 07.2^{\prime} \mathrm{E}$ & $\begin{array}{l}\text { Manala River, west side of Soarano } \\
\text { structure }\end{array}$ \\
\hline 15 & MAD00-29 & Quartzite & $20^{\circ} 14.3^{\prime} \mathrm{S}$ & $46^{\circ} 11.9^{\prime} \mathrm{E}$ & $\begin{array}{l}\text { Ampasimandrevo Mountain, north of } \\
\text { Mangataboahangy }\end{array}$ \\
\hline 16 & MAD 00-36 & Bt-Cd gneiss & $20^{\circ} 19.3^{\prime} \mathrm{S}$ & $46^{\circ} 13.7^{\prime} \mathrm{E}$ & South of Modia village \\
\hline 17 & MAD 00-39/40 & Quartzite & $20^{\circ} 22.9^{\prime} \mathrm{S}$ & $46^{\circ} 13.7^{\prime} \mathrm{E}$ & North of Menavato village \\
\hline A & MAD 93-132 & Marble & $20^{\circ} 25.60^{\prime} \mathrm{S}$ & $46^{\circ} 46.9^{\prime} \mathrm{E}$ & Begabona, north of Ambatofinandrahana \\
\hline B & MAD 94-10 & Marble & $20^{\circ} 29.24^{\prime} \mathrm{S}$ & $46^{\circ} 50.64^{\prime} \mathrm{E}$ & $\begin{array}{l}\text { Ambohitsipanefy, north of } \\
\text { Ambatofinandrahana }\end{array}$ \\
\hline $\mathrm{C}$ & MAD 94-52 & Marble & $20^{\circ} 35.40^{\prime} \mathrm{S}$ & $46^{\circ} 49.60^{\prime} \mathrm{E}$ & Magrama, south of Ambatofinandrahana \\
\hline
\end{tabular}

Note. Numbers and letters in leftmost column are keyed to figures 1 and 3 as well as subsequent data tables.

can inform our understanding of orogenic belt evolution thanks to SHRIMP U-Pb analysis of internally complex zircon grains coupled with statistical methods for analyzing age spectra of mixed populations and compound data sets (Dodson et al. 1988; Cawood et al. 1999; Bodorkos et al. 2000; Sircombe $2000 a, 2000 b$ ). We therefore present data from the metasedimentary Itremo massif of central Madagascar (fig. 1; table 1).

The Itremo massif includes biotite- to sillimanitezone clastic and carbonate rocks (Moine 1968) of debated stratigraphic affinity (see summary in Fernandez et al. 2003). Among these is the Itremo Group, a metamorphosed sequence of shallowmarine quartzites, carbonates, and pelitic rocks, deposited in a pre-Gondwana passive continental margin or intracontinental basin setting (Moine 1974; Cox et al. 1998). The Itremo Group was intruded by granitic and gabbroic plutons in the intervals 804$779 \mathrm{Ma}$ and 571-536 Ma (Handke et al. 1999; Handke 2001). It has undergone polyphase deformation (Collins et al. 2003b) and at least one episode of metamorphism up to sillimanite grade at about $560 \mathrm{Ma}$ (Cox et al. 2001).

Existing interpretations of the stratigraphic and structural relations among Itremo massif units are based on petrologic/lithologic analysis (Moine 1974; Cox et al. 1998; Fernandez and Schreuers 2003), but this does not provide unique interpretations in zones of extreme deformation and metamorphism such as in the west and south of the Itremo massif, where metamorphic grade is in the granulite facies. Zircon geochronology from metasedimentary rocks provides information on provenance (hence predeformation paleogeography) and places limits on depositional age as well as the timing of metamorphic events.

We provide a chronostratigraphic framework for Proterozoic metasedimentary rocks in the Itremo massif of central Madagascar. We confirm continuity of the Itremo Group into the upper amphibolite and granulite facies rocks of the western Itremo massif based on homogeneity of detrital zircon age populations. We identify a previously unrecognized younger metasedimentary unit, the Molo Group, which is not distinguished from other sillimanite-bearing quartzites by spectral characteristics (Fernandez and Schreuers 2003) or by lithologic characteristics (Moine 1968) but rather is recognized solely based on detrital zircon popula- 
tions. Finally, we characterize the provenance of both the Itremo and Molo Group metasediments to constrain preorogenic sedimentary connections between Madagascar and neighboring regions and propose paleogeographic connections on that basis.

\section{Geochronology Methods}

Geochronology and Carbon Isotope Analysis. Quartzite samples providing broad coverage of the Itremo massif (fig. 1) were selected for detrital zircon SHRIMP U-Pb analysis. Standard crushing, density, and magnetic separation techniques were used to isolate zircon grains, which were mounted in epoxy, polished, and coated with gold for analysis. All zircon grains were imaged under a scanning electron microscope by cathodoluminescence before analysis. Grain selection was based on grain size and clarity; small grains and metamict grains are therefore underrepresented in the data set. Such grains, however, were rarely encountered.

Analyses also were performed on three marbles from the central part of the Itremo massif (fig. 1) by L. D. White at USGS Menlo Park. Samples were well-preserved stromatolitic limestones from a low-strain area in the core of a large recumbent fold (compare locations in fig. 1 with fig. 2 in Cox et al. 1998).

The data presented here come from detrital zircons in metamorphosed clastic sedimentary rocks. The detrital zircons show abrasion and rounding, crystal faces are absent, and internal zonation is truncated (fig. 2; see also Cox et al. 1998, their fig. 3). Where metamorphic zircon has overgrown the detrital grains, sharply faceted unabraded crystal forms envelop the rounded and broken detrital cores (fig. 2). There is a clear distinction between the brighter, finely zoned cores and the darker, more crudely zoned metamorphic overgrowths. The overgrowths have low average $\mathrm{Th} / \mathrm{U}$ values ( 0.02) and high $U$ concentrations ( 200-2500 ppm), characteristic of metamorphic growth (Williams and Claesson 1987; Vavra et al. 1999), and they are concordant, with an average age of $556 \pm 10 \mathrm{Ma}$, MSWD 0.58 (R. Cox, unpublished data). The detrital grains exhibit well-defined finescale concentric oscillatory and sector zoning that suggests an igneous origin, based on criteria of Vavra (1990) and Whitehouse et al. (1999). Uranium concentrations in the detrital cores, which average $213 \mathrm{ppm}$, and $\mathrm{Th} / \mathrm{U}$ values, averaging 0.7 (table 2 in the online edition of the Journal of Geology or available from the Journal's Data Depository in the

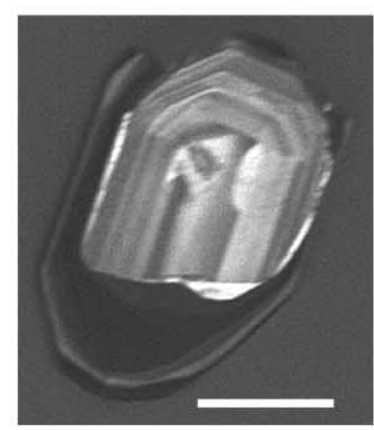

MAD 00-11:2

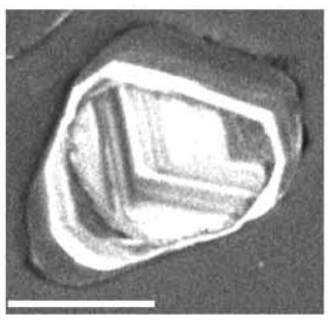

MAD 00-29:6

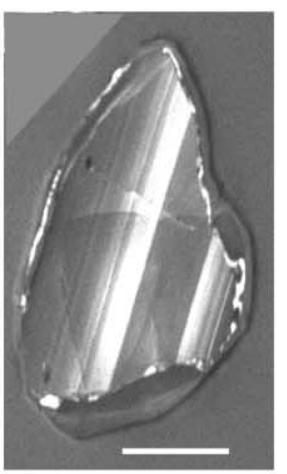

MAD 00-04:10

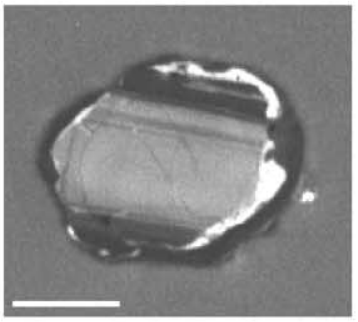

MAD 00-09:12

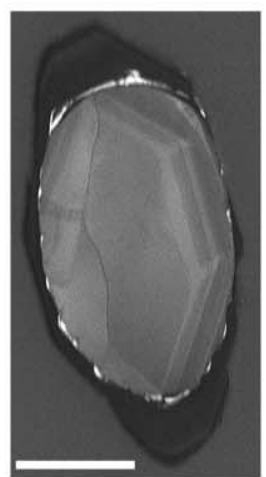

MAD 00-39/40:12

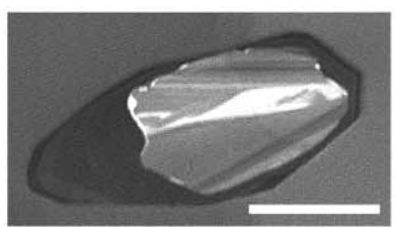

MAD 00-39/40:11

A

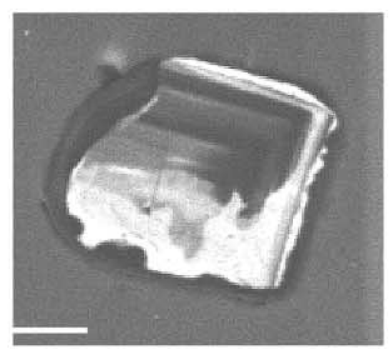

MAD 00-09:13

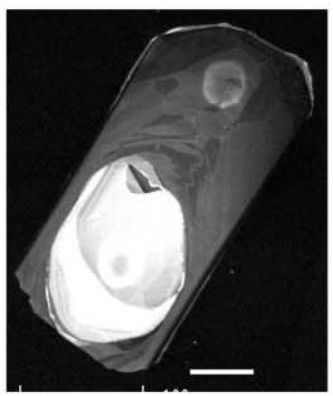

Collins 32/98:33
Figure 2. Detrital zircon grains with metamorphic overgrowths of varying thickness. $A$, Itremo Group; $B$, Molo Group. Scale bars are $50 \mu \mathrm{m}$. Grain identification numbers include sample number and SHRIMP spot number; see table 2 in the online edition of the Journal of Geology for detrital core ages. Ages of overgrowths average $556 \pm 10 \mathrm{Ma}$ and are reported elsewhere (Cox et al., unpublished data). 
Table 3. Detrital Zircon Age Populations for the Itremo Group $\left({ }^{207} \mathrm{~Pb} /{ }^{206} \mathrm{~Pb}\right.$ Ages $)$

\begin{tabular}{|c|c|c|c|c|c|c|}
\hline Itremo Group & $N$ & $\begin{array}{l}\text { Age range } \\
(\mathrm{Ma})\end{array}$ & $\begin{array}{c}\text { No. age } \\
\text { components }\end{array}$ & $\begin{array}{c}{ }^{206} \mathrm{~Pb} /{ }^{238} \mathrm{U} \\
\text { population } \\
\text { mean age }\end{array}$ & $\pm 1 \sigma$ & $\begin{array}{l}\text { No. } \\
\text { grains }\end{array}$ \\
\hline 14 samples combined & 143 & $1722-2726$ & 7 & $\begin{array}{l}1852^{\mathrm{a}} \\
1968^{\mathrm{a}} \\
2080^{\mathrm{a}} \\
2196^{\mathrm{a}} \\
2500^{\mathrm{a}} \\
2633^{\mathrm{a}} \\
2701^{\mathrm{a}}\end{array}$ & $\begin{array}{l}3 \\
5 \\
4 \\
4 \\
2 \\
6 \\
4\end{array}$ & $\begin{array}{r}39 \\
10 \\
11 \\
15 \\
50 \\
3 \\
15\end{array}$ \\
\hline $\begin{array}{l}\text { Outlier (in sample 12) } \\
\text { Outlier (in sample 15) }\end{array}$ & $\begin{array}{l}1 \\
1\end{array}$ & & $\begin{array}{l}1 \\
1\end{array}$ & $\begin{array}{l}2877 \\
3428\end{array}$ & $\begin{array}{l}27 \\
28\end{array}$ & $\begin{array}{l}1 \\
1\end{array}$ \\
\hline $\begin{array}{l}\text { Total number of age } \\
\text { components }\end{array}$ & & & 9 & & & \\
\hline
\end{tabular}

Note. The populations were determined by mixture modeling based on the methods of Sambridge and Compston (1994) and using the program MIX (written by K. Gallagher and M. Sambridge). The data sets are large enough to give statistically reliable information about the constituent populations; using Dodson et al.'s (1988) test for statistical adequacy as graphed by Sircombe (2000a), the exclusion probability is $<5 \%$ for age groups comprising as little as $2 \%$ of the Itremo Group zircon population. The mixture modeling results are reported as best-fit age ranges that represent a probability density derived from the detrital grain suites; that is, they are related to but not the same as the absolute age ranges of source-rock suites (Sircombe 2000b). The outlier age in sample 12 was excluded from mixture modeling because it clearly represents a separate population.

${ }^{\mathrm{a}} \chi^{2}=6.9 ;$ misfit $=445$.

Journal of Geology office upon request), are also consistent with an igneous predetrital origin.

Reported data include only analyses $100 \% \pm$ $5 \%$ concordant with $1 \sigma$ errors less than $4 \%$ of the age. We use ${ }^{207} \mathrm{~Pb} /{ }^{206} \mathrm{~Pb}$ ages (and errors) for statistical analysis of populations with ages $>1400 \mathrm{Ma}$ and ${ }^{238} \mathrm{U} /{ }^{206} \mathrm{~Pb}$ ages (and errors) for analysis of younger populations because grains younger than approximately $1400 \mathrm{Ma}$ have significantly more precise ${ }^{238} \mathrm{U} /{ }^{206} \mathrm{~Pb}$ ages than ${ }^{207} \mathrm{~Pb} /{ }^{206} \mathrm{~Pb}$ ages as a result of extremely low ${ }^{207} \mathrm{~Pb}$ abundances in young grains. The ${ }^{207} \mathrm{~Pb} /{ }^{206} \mathrm{~Pb}$ and ${ }^{238} \mathrm{U} /{ }^{206} \mathrm{~Pb}$ ages are indistinguishable (because the points are concordant), but using the ages with smaller errors maximizes the distinction of age populations and reduces the possibility that grains from disparate age populations will be binned together simply because their ages overlap at the limits of the errors.

Mixture Modeling. Mixture modeling (Sambridge and Compston 1994) by means of the MIX program (version 21.1.97 by K. Gallagher and M. Sambridge) was used to quantify age populations in the detrital zircon data sets. Iterative application of the mixture modeling algorithm, each time incrementing the number of age components, generates the optimum number of age components to satisfy the frequency distribution of the data. Age probability curves were plotted independently using Isoplot/Ex 2.49 (by Ken Ludwig). Three conditions characterize the optimum number of components: (1) The misfit of the solution (the negative log of the likelihood function) is stabilized: as the number of age com- ponents increases toward the optimum, the misfit value decreases. Beyond the optimum, further increase in the number of components produces no significant reduction in the misfit value (Sambridge and Compston 1994). (2) $\chi^{2}$ is minimized: $\chi^{2}$ decreases with increasing component number until the optimum number is reached, at which point it begins to increase again. Note that $\chi^{2}$ is not used as a measure of statistical reliability but as an indicator value. For this data set, $\chi^{2}$ values are never very low because there is substantial geological scatter in the data. (3) The ages and proportions produced by MIX visually match the frequency distribution of the detrital data (Sambridge and Compston 1994). For the data presented here, the optimum number of age components (tables 3, 4), as determined by $\chi^{2}$ and misfit values, matches the number of peaks in the Isoplot-generated age probability curves.

\section{Geochronology Results}

SHRIMP ages for the zircons analyzed fall into two distinct sets (table 2; fig. 3). Samples 1-3, representing the Molo Group (Cox et al. 2001), are characterized by zircon that is late Meso- to Neoproterozoic in age. Itremo Group samples (4-17) contain only Paleoproterozoic and Archean detrital zircon. Detrital zircons from both suites have metamorphic overgrowths that are dated at $556 \pm 10 \mathrm{Ma}$ (Cox et al. 2001; R. Cox, unpublished data). 
Table 4. Detrital Zircon Age Populations in Molo Group Samples $\left({ }^{206} \mathrm{~Pb} /{ }^{238} \mathrm{U}\right.$ Ages)

\begin{tabular}{|c|c|c|c|c|c|c|}
\hline & $N$ & $\begin{array}{l}\text { Age range } \\
\text { (Ma) }\end{array}$ & $\begin{array}{c}\text { No. age } \\
\text { components }\end{array}$ & $\begin{array}{l}{ }^{206} \mathrm{~Pb} /{ }^{238} \mathrm{U} \\
\text { population } \\
\text { mean age }\end{array}$ & $\pm 1 \sigma$ & $\begin{array}{l}\text { No. } \\
\text { grains }\end{array}$ \\
\hline \multicolumn{7}{|l|}{ MOLO GROUP: } \\
\hline \multirow[t]{8}{*}{ Three samples combined } & 61 & $613-2519$ & 8 & $635^{\mathrm{a}}$ & 2 & 9 \\
\hline & & & & $687^{\mathrm{a}}$ & 6 & 2 \\
\hline & & & & $782^{\mathrm{a}}$ & 4 & 10 \\
\hline & & & & $837^{\mathrm{a}}$ & 5 & 8 \\
\hline & & & & $901^{\mathrm{a}}$ & 8 & 6 \\
\hline & & & & $971^{\mathrm{a}}$ & 5 & 7 \\
\hline & & & & $1030^{\mathrm{a}}$ & 5 & 11 \\
\hline & & & & $1087^{\mathrm{a}}$ & 6 & 8 \\
\hline Outlier (in sample 3) & 1 & & 1 & 1458 & 34 & 1 \\
\hline Outlier (in sample 3) & 1 & & 1 & 2243 & 17 & 1 \\
\hline Outlier (in sample 3) & 1 & & 1 & 2519 & 69 & 1 \\
\hline Outlier (in sample 2) & 1 & & 1 & 2927 & 36 & 1 \\
\hline Total number of age components & & & 12 & & & \\
\hline \multicolumn{7}{|l|}{ INDIVIDUAL SAMPLES: } \\
\hline \multirow[t]{5}{*}{ 1. MAD 00-04 quartzite } & 20 & $788-1121$ & 5 & $806^{\mathrm{b}}$ & 7 & 3 \\
\hline & & & & $850^{\mathrm{b}}$ & 7 & 3 \\
\hline & & & & $905^{\mathrm{b}}$ & 9 & 4 \\
\hline & & & & $979^{\mathrm{b}}$ & 5 & 6 \\
\hline & & & & $1037^{b}$ & 7 & 4 \\
\hline \multirow[t]{6}{*}{ 2. MAD 00-09 pelitic gneiss } & 22 & $613-2297$ & 6 & $629^{c}$ & 3 & 8 \\
\hline & & & & $779^{\mathrm{c}}$ & 4 & 8 \\
\hline & & & & $829^{\mathrm{c}}$ & 5 & 3 \\
\hline & & & & $967^{\mathrm{c}}$ & 12 & 1 \\
\hline & & & & $1024^{\mathrm{c}}$ & 8 & 2 \\
\hline & & & & $2927^{\mathrm{c}}$ & 36 & 1 \\
\hline \multirow{6}{*}{ 3. Collins 32/98 psammite } & 23 & $654-2519$ & 6 & $669^{\mathrm{d}}$ & 4 & 3 \\
\hline & & & & $1036^{\mathrm{d}}$ & 8 & 6 \\
\hline & & & & $1089^{\mathrm{d}}$ & 6 & 9 \\
\hline & & & & $1458^{\mathrm{d}}$ & 34 & 1 \\
\hline & & & & $2243^{\mathrm{d}}$ & 17 & 1 \\
\hline & & & & $2519^{\mathrm{d}}$ & 69 & 1 \\
\hline \multicolumn{7}{|l|}{ EAST ANTARCTICA: } \\
\hline \multirow{6}{*}{$\begin{array}{l}\text { Yamato Mountains pyroxene-biotite } \\
\text { gneiss (from Shiraishi et al. 1994: con- } \\
\text { cordant data only) }\end{array}$} & & & & & & \\
\hline & 11 & $633-2319$ & 5 & $645^{\mathrm{e}}$ & 8 & 3 \\
\hline & & & & $758^{\mathrm{e}}$ & 10 & 3 \\
\hline & & & & $957^{\mathrm{e}}$ & 12 & 3 \\
\hline & & & & $1127^{\mathrm{e}}$ & 26 & 1 \\
\hline & & & & $2319^{\mathrm{e}}$ & 48 & 1 \\
\hline
\end{tabular}

Note. The exclusion probability is less than 0.05 for age groups comprising $10 \%$ of the Molo group zircon population. See table 3 legend for details. The outlier ages are not included in the mixture modeling analysis because they represent unambiguously distinct populations.

${ }^{\mathrm{a}} \chi^{2}=7.5$; misfit $=173$

${ }^{\mathrm{b}} \chi^{2}=8.7$; misfit $=48$.

${ }^{c} \chi^{2}=9.5$; misfit $=51$.

${ }^{\mathrm{d}} \chi^{2}=9.4$; misfit $=66$.

${ }^{\mathrm{e}} \chi^{2}=10.7$; misfit $=35$.

Mixture modeling analysis of the Itremo Group zircon data reveals nine provenance components ranging from early Archean (1 grain only) to Paleoproterozoic (table 3). The dominant detrital populations cluster at $1850 \mathrm{Ma}(39 / 145$ grains) and 2500 $\mathrm{Ma}$ (50/145 grains), with prominent secondary peaks near 2200 and $2700 \mathrm{Ma}$ (table 3; fig. 4A). There are no detrital grains younger than $1720 \mathrm{Ma}$, and only two are older than $2701 \mathrm{Ma}$.
Molo Group samples present 12 provenance components in aggregate (table 4), with substantial overlap between the three samples analyzed (fig. 3). The populations form three clusters, centered about 630-690 Ma, 780-840 Ma, and 1030-1090 Ma (table 4; fig. 4A). Of these, the $1030 \pm 5$ Ma population is present in all samples, and the others are each seen in two of the three samples. The oldest provenance components $(>1090 \mathrm{Ma})$ are repre- 


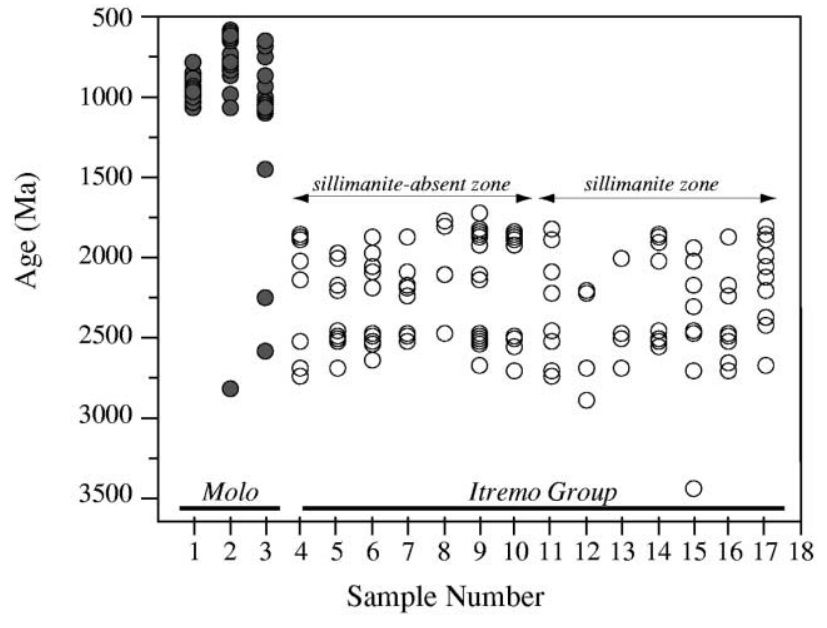

Figure 3. U-Pb detrital zircon ${ }^{207} \mathrm{~Pb} /{ }^{206} \mathrm{~Pb}$ ages (data from table 2 in the online edition of the Journal of Geology). Each point represents a single detrital grain age, but not all are visible because of overlap. Sample numbers correspond to figure 1 and to tables $1-4$. The sillimaniteabsent and sillimanite (Sill + Mu and Sill + Ksp, respectively) metamorphic zones are shown in figure 1 .

sented only by single grains. Only three of 65 detrital zircons have ages that overlap with Itremo Group zircon data (table 4; fig. 4A).

\section{Age and Stratigraphic Relationships of the Sedimentary Sequences}

Paleoproterozoic Itremo Group. The Itremo Group was probably deposited at around $1700 \mathrm{Ma}$. Three lines of evidence suggest that its age is close to that of the youngest detrital zircon analyzed (1722 $\pm 40 \mathrm{Ma}$; table 2).

The detrital zircon data set shows a complete spectrum of ages from late Archean through most of the Paleoproterozoic, but there is a total absence of Mesoproterozoic grains, in stark contrast to their abundance in the superjacent Molo Group (fig. 3). This suggests that Itremo Group deposition predated the Mesoproterozoic.

Stromatolites, ubiquitous in Itremo Group dolomitic marbles (Cox et al. 1998), exhibit the characteristics (Hofmann 1987; James and Narbonne 2002; Olcott et al. 2002) of Paleoproterozoic stromatolites. Their morphology is uniformly simple, and they record only a small number of forms. Domal and pseudocolumnar forms dominate (fig. $5 a-5 e)$, often accompanied by cryptalgal laminates (fig. $5 a, 5 c$ ). No branching forms occur. Synoptic relief ranges from 3 to $30 \mathrm{~cm}$, with vertical inheritance from 20 to $100 \mathrm{~cm}$. They do not form isolated bioherms but occur as laterally persistent, stacked, flat-lying biostromal layers. Ministromatolites (Hofmann and Jackson 1987) are occasionally found (fig. $5 f$ ) in rare localities with peritidal characteristics. The extreme simplicity of the stromatolite structures, especially in the context of their widespread occurrence, strongly suggests a Paleoproterozoic age (A. Knoll, personal communication).

Whole-rock $\delta^{13} \mathrm{C}$ values for stromatolitic marble are consistent with a Paleoproterozoic age (fig. 6). Globally, Paleoproterozoic and early Mesoproterozoic marine carbon isotope values show little variability: between about 1850 and $1250 \mathrm{Ma}, \delta^{13} \mathrm{C}$ values range only from $-2 \%$ to $+2 \%$ (Anbar and Knoll 2002, and references therein). The Itremo Group $\delta^{13} \mathrm{C}$ values do not preclude a younger age, but their similarity to known Paleoproterozoic values combines with the other lines of evidence to build a strong circumstantial case for pre-Mesoproterozoic deposition. In our opinion, Itremo Group sedimentation definitely does not postdate $1500 \mathrm{Ma}$ and is probably closer to $1700 \mathrm{Ma}$.

Neoproterozoic Molo Group. The Molo Group is younger than the Itremo Group. It includes detrital zircon grains of the same age as and younger than the 804-779 Ma plutons (Handke et al. 1999) that intrude the Itremo Group (Cox et al. 1998; Handke et al. 1999; Collins et al. 2003b). The depositional age of the Molo Group is between $613 \pm 9 \mathrm{Ma}$, the age of the youngest detrital zircon (table 2), and $556 \pm 10 \mathrm{Ma}$, the average age of metamorphic overgrowths on the detrital grains (Cox et al. 2001; R. Cox, unpublished data).

Stratigraphic Relationships. There is debate about Itremo Group stratigraphy and extent. Fernandez and Schreurs (2003) distinguish sillimanitebearing (high-grade) from non-sillimanite-bearing (low-grade) quartzite using spectral analysis. They interpret only the low-grade rocks as Itremo Group and consider the high-grade quartzite to represent structurally underlying basement. We disagree with this and interpret the presence or absence of sillimanite to indicate only differing grade of metamorphism. Identical detrital zircon populations occur in both the high- and low-grade quartzite (fig. 3). In addition, there is a high angle between mapped isograds and lithologic contacts (fig. 1), and outcrop geology shows a continuum between coarsely crystalline, sillimanite-bearing quartzite and finer-grained, micaceous, non-sillimanitebearing quartzite (Raoelison 1997; Cox et al. 1998).

Itremo Group basement-cover relationships remain unclear. The sedimentary rocks may be unconformable on migmatitic gneisses (Cox et al. 1998), but the boundaries are strongly tectonized, 

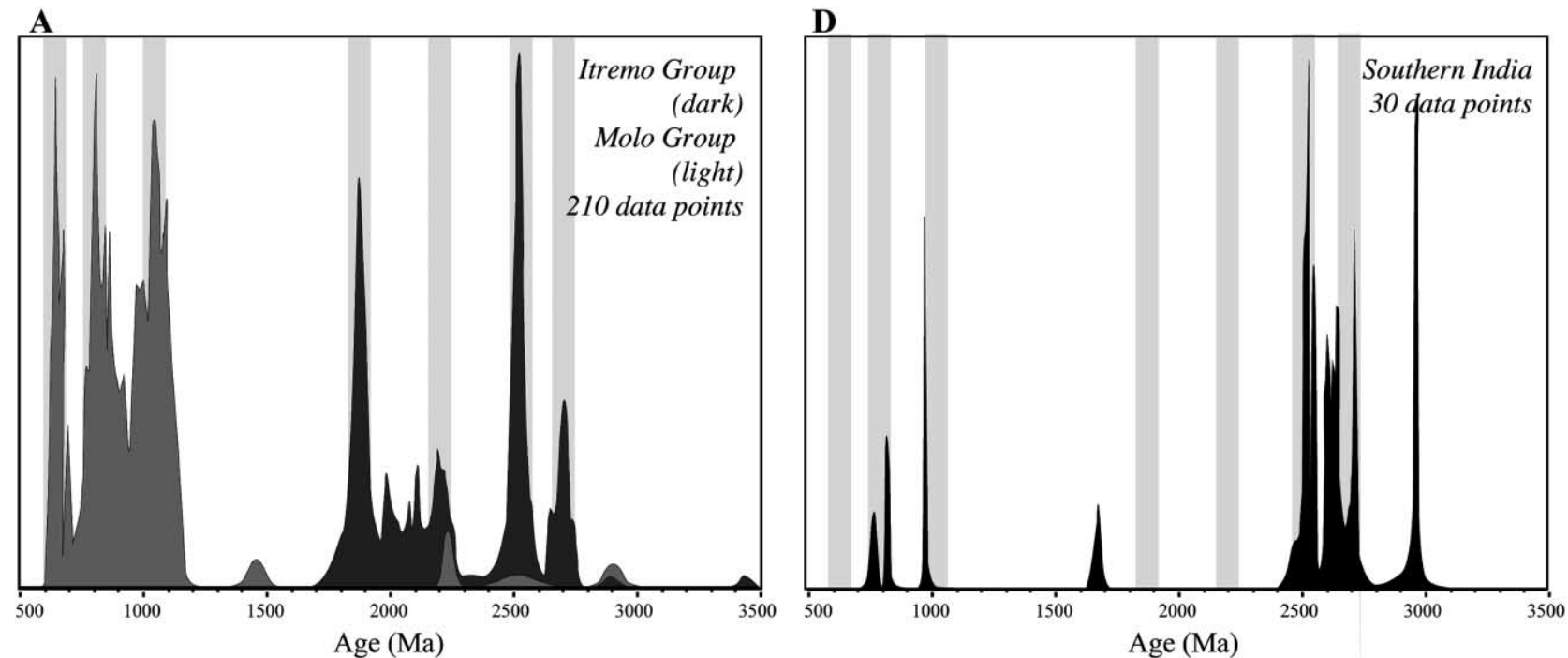

B

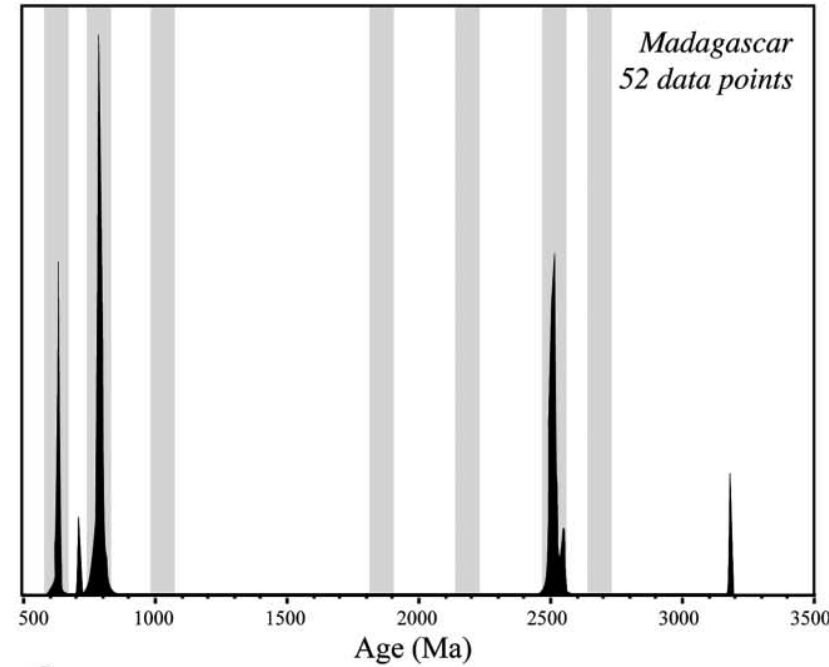

C

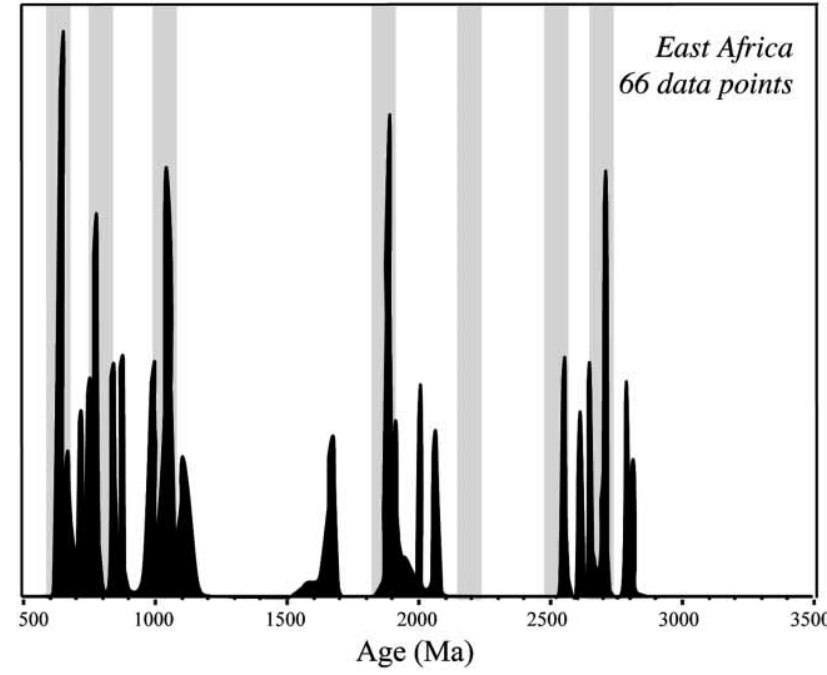

E

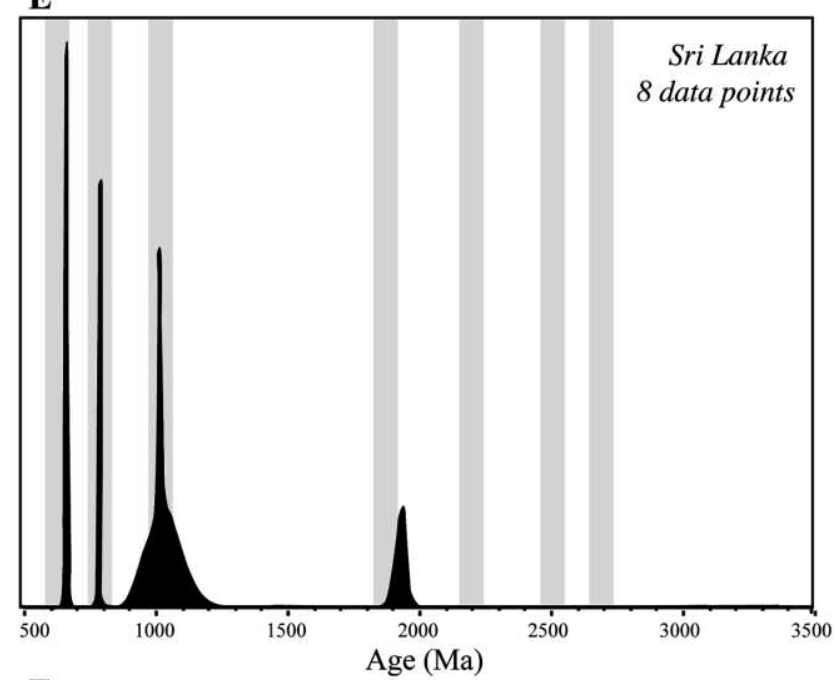

F

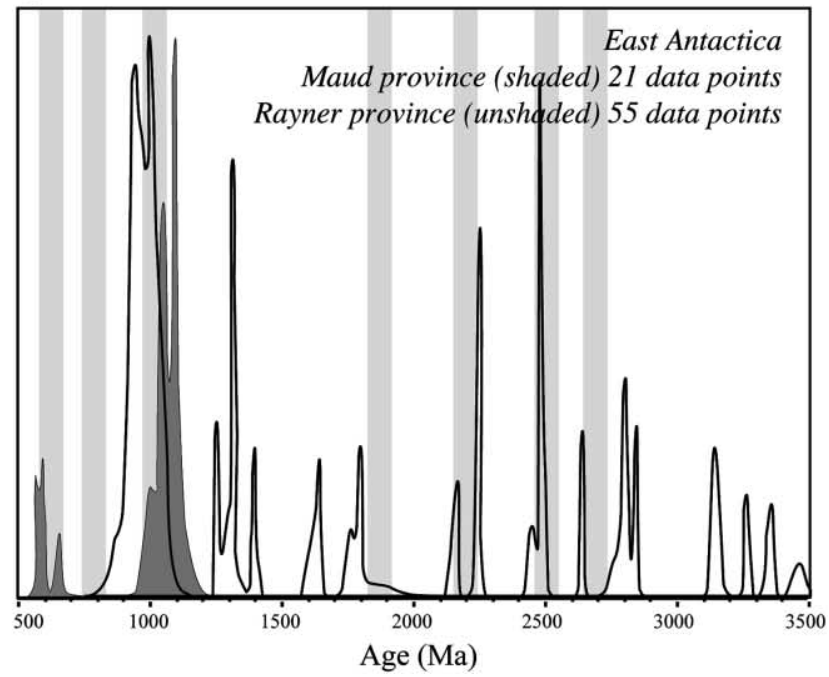


either faulted as at the eastern margin (Daso 1986; Collins et al. 2000) or intimately interleaved with high-grade gneisses as in the west and south ( R. Cox, unpublished data).

Molo Group rocks occur along the western edge of the Itremo Group outcrop belt, but because of granulite-facies metamorphism and lack of lithologic contrast, additional sampling and mapping are required to better characterize the outcrop area. In addition to the localities documented here, the Molo Group may occur intercalated with Itremo Group sediments at Ihosy (fig. 7 inset; about $60 \mathrm{~km}$ southwest of sample site 3). Biotitesillimanite-cordierite gneiss from the Ihosy quarry yields detrital zircons with well-constrained $\mathrm{Pb}-\mathrm{Pb}$ ages (Kröner et al. 1996) of 1835 and 1855 $\mathrm{Ma}$, characteristic of the Itremo Group, and a quartzofeldspathic gneiss from the same quarry produces detrital ages of 720,884 , and $1425 \mathrm{Ma}$, matching Molo Group populations. This indicates that both the Itremo and Molo Groups may extend well south of the known Itremo Group outcrop area and even south of the Bongolava-Ranotsara shear zone (BRSZ, fig. 7 inset), with their mappable identities obscured by intense deformation and metamorphism.

The tectonostratigraphic relationship between the Itremo and Molo Groups is ambiguous. Two Proterozoic grains in Molo Group sample 3 match detrital zircon ages in the Itremo Group, but we cannot determine whether these grains were recycled from the Itremo Group or whether they represent provenance overlap. In general, however, the Molo Group did not receive sediment from the Itremo Group source rocks, and it does not record large-scale recycling of the Itremo Group (fig. 3). Possible scenarios include:

1. The sedimentary sequences were deposited in separate areas and tectonically juxtaposed during Gondwana assembly at approximately $550 \mathrm{Ma}$. This does not seem likely as the Molo Group rocks appear to be intimately interleaved with the Itremo
Group, and there is no map-scale evidence for separate tectonic packages that may have been transported hundreds of kilometers.

2. The Molo Group sediments were deposited above the Itremo Group and its source rocks, which were buried and shed little or no detritus at the time of Molo Group deposition. The source area for the Molo Group was dominated by $900-1100-\mathrm{Ma}$ rocks, which are not seen in present-day Madagascar but must have been nearby during the Neoproterozoic. We prefer this interpretation for reasons discussed below.

\section{Provenance Analysis}

Cox et al. (1998) compared Itremo Group detrital zircon ages with data from potential source areas and proposed an east African source for the sediment. With the growth of U-Pb data sets we can now make a more thorough analysis, although we note that the basement ages in the potential source regions are still quite poorly known. To evaluate provenance relationships between the Molo and Itremo Groups and their possible source areas: east Africa (Tanzanian craton, Mozambique belt, and Kaapvaal/Kalahari craton), southern India (Dharwar craton, Nilgiri Hills, and Madurai and Trivandrum blocks), Sri Lanka, and the region of East Antarctica from the Maud province to the Napier complex (fig. 7), we compare the age distribution of detrital grains from this study with published U$\mathrm{Pb}$ ages for rocks in neighboring Gondwana terranes (sources listed in the appendix in the online edition of the Journal of Geology or available from the Journal's Data Depository in the Journal of Geology office upon request).

We apply the following criteria to make the comparison as direct and unambiguous as possible: (1) Only SHRIMP and conventional U/Pb zircon ages are included to permit direct comparison of the basement data with our detrital zircon data. (2) Only data from igneous rocks and ortho-

Figure 4. Age-probability curves for zircon populations, generated by Isoplot/Ex (version 2.49, Ken Ludwig). Input parameters are ages and $1 \sigma$ errors. See Stewart et al. (2001) for general description of construction method. Pale gray zones indicate major detrital age populations in the Itremo and Molo Groups, for comparison with spikes in basement age populations in potential source areas. $A$, Data from the Molo and Itremo Groups. $B-F$, Published concordant $U$ $\mathrm{Pb}$ zircon ages 600-3500 Ma from igneous rocks and orthogneisses in Gondwana terrains adjacent to Madagascar (see appendix in the online edition of the Journal of Geology for data sources). Data in B-F include single ages and averages of multiple analyses, but no rock unit is represented by more than one data point. East Africa includes Mozambique, Zimbabwe, Tanzania, Kenya, Ethiopia, and Somalia; India covers southern and western India, as far north as the Aravalli-Delhi belt. East Antarctic data are separated into Rayner Province, from Enderby Land to Prydz Bay (unshaded) and Maud Province, including Dronning Maud Land and Coats Land (shaded). 
a.
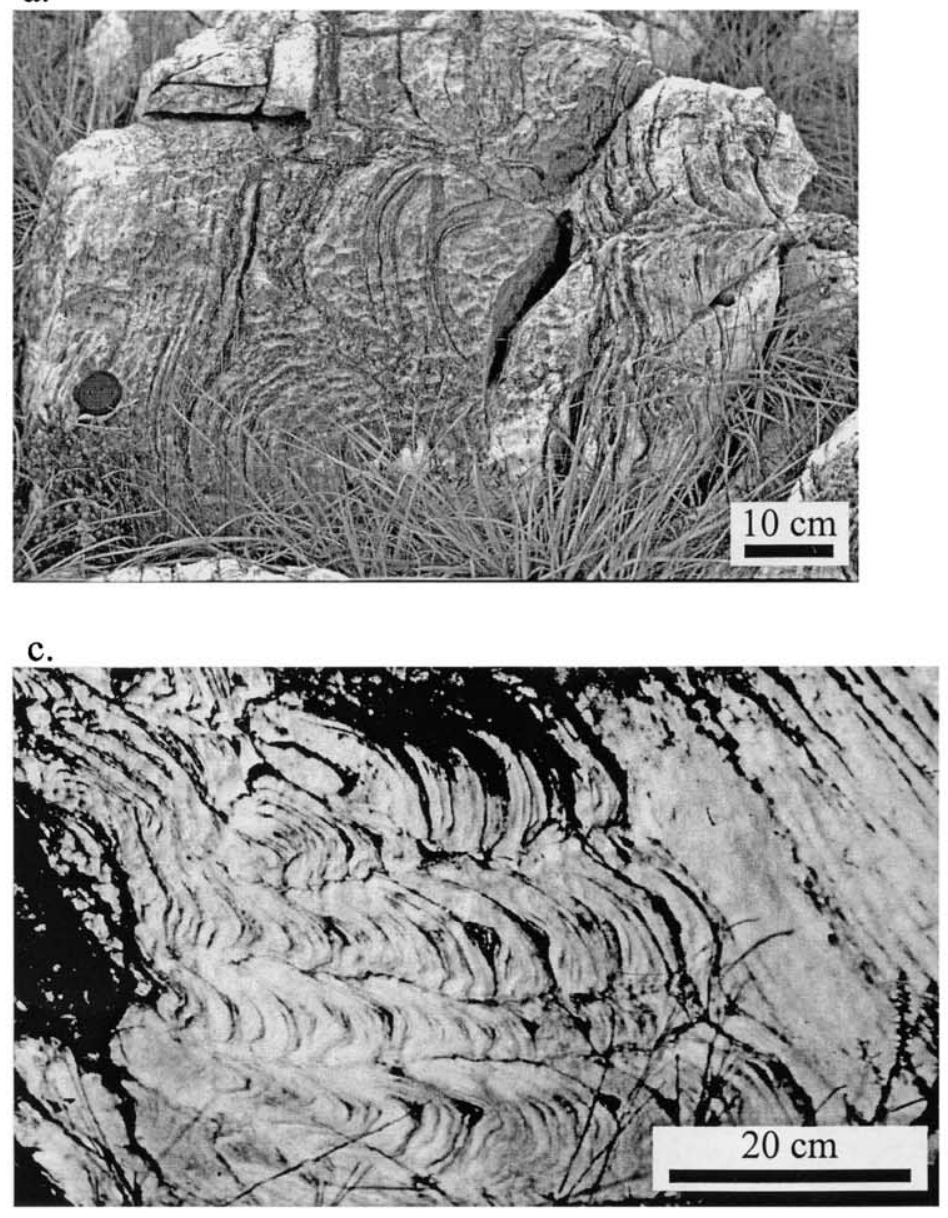

b.

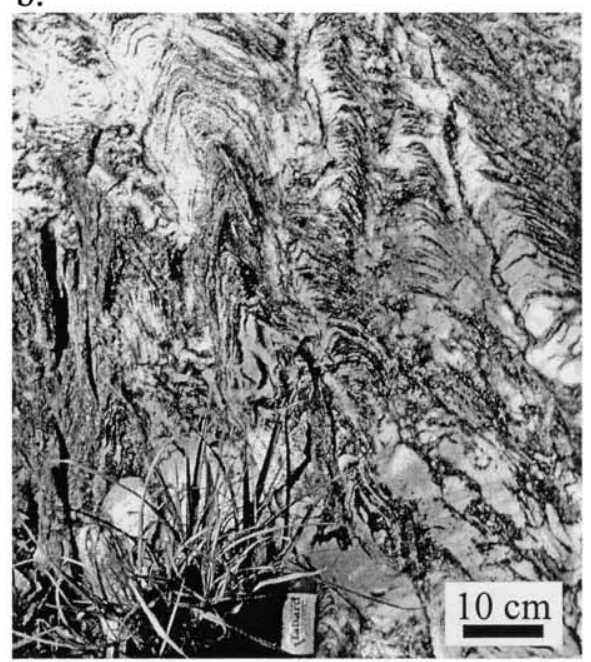

d.

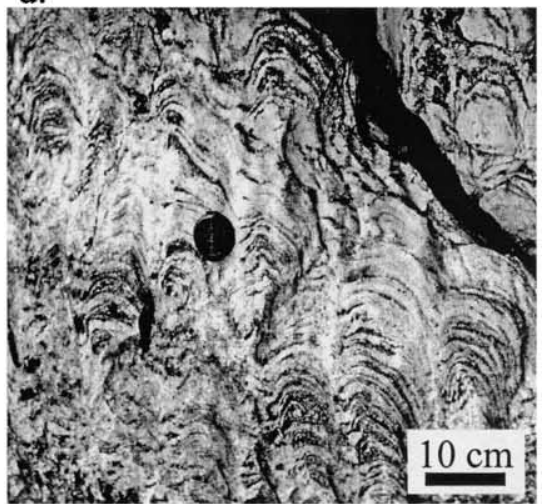

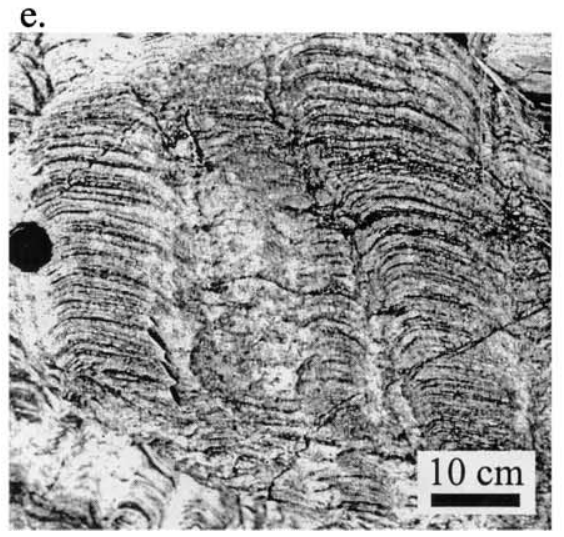

f.

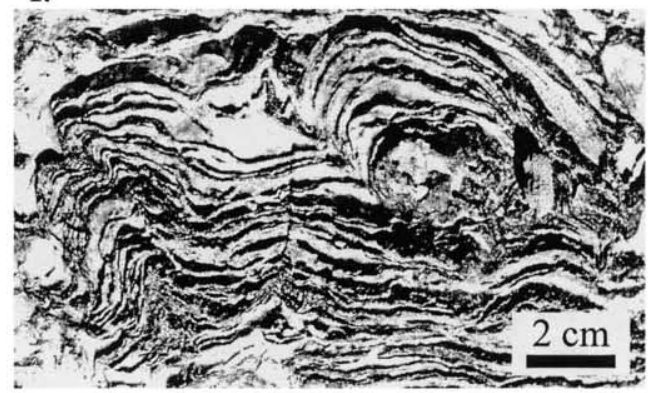

Figure 5. Stromatolite morphologies preserved in low-strain areas in the sillimanite-absent portion of the outcrop area (see fig. 1). Features are preserved on weathered surfaces only. Pervasive recrystallization to coarse dolomite has obscured all internal fine detail, and no microstructural analysis is possible.

gneisses are included. Xenocryst and detrital zircon data are excluded because they do not represent primary source rocks and their proximity and sediment source significance are therefore less clear. (3) Only concordant ages are included. Ages more than $5 \%$ discordant are excluded, and concordant data with errors $>4 \%$ of the age are also excluded. Ages derived from upper and lower intercepts of discordant data are not included, even if the data are strongly collinear with low MSWD 
values, producing good source rock ages. The rationale is that sediment transport biases the detrital data set against metamict grains, so these source-rock ages would not be seen in the detrital record.

Itremo Group Provenance. Two detrital zircon age populations dominate the Itremo Group at 1850 and $2500 \mathrm{Ma}$ (figs. 3, 4a), and there are a number of smaller significant peaks (detailed in table 3). Electron microprobe Th-U-Pb ages from 11 detrital monazites in Itremo Group pelites (Fernandez et al. 2003) are consistent with these data and form clusters near 1700 and $2000 \mathrm{Ma}$. There is a marked uniformity of ages in samples from across the outcrop belt (fig. 3), indicating thorough predepositional mixing of Itremo Group source materials. The provenance signatures therefore represent an integrated average of exposed basement in the continental source area and can be directly compared to regional basement geochronology from potential source areas in neighboring Gondwana fragments.

Rocks with ages around $2500 \mathrm{Ma}$ (fig. 4B) are widespread throughout Madagascar (Tucker et al. 1999b; Kröner et al. 2000), and these basement ages precisely match the biggest Itremo detrital age peak at $2500 \mathrm{Ma}$ (fig. 4A). We therefore interpret this large peak to represent local sources and so do not consider its presence or absence in Gondwana neighbors to be diagnostic of provenance. There are, however, no precise $\mathrm{U}-\mathrm{Pb}$ ages in Madagascar corresponding to the 1850-Ma detrital peak (fig. $4 B$ ). $\mathrm{Pb}-\mathrm{Pb}$ ages of 1710-1890 Ma (Kröner et al. 1999) and a discordia upper-intercept age of $1840 \mathrm{Ma}$ (Müller 2000) reported from southern Madagascar indicate a small basement component of this age, but the abundance of 1850-Ma ages in every Itremo Group sample analyzed indicates derivation from a source with a large volume of $1850-\mathrm{Ma}$ basement rocks. The lack of source rocks in Madagascar in the interval 1700-2300 Ma strongly suggests a source outside of Madagascar in the neighboring Gondwana terranes.

Eastern Africa, alone among the source candidates, provides a basement-detrital zircon age match for all identified populations in the Itremo Group (fig. 4C). For the prominent detrital age peak at $1850 \mathrm{Ma}$, which has no Malagasy basement counterpart, African basement matches are found in gneisses beneath the Katangan Supergroup (Ngoyi and Dejonghe 1995; Rainaud et al. 1999), in the Zambian Irumide belt (De Waele and Mapani 2002; B. De Waele, unpublished data), and in the Usagaran and Mozambique belts of Tanzania (Reddy et al., in press; Sommer et al., in press). The detrital zircon peak at 1960 Ma matches basement

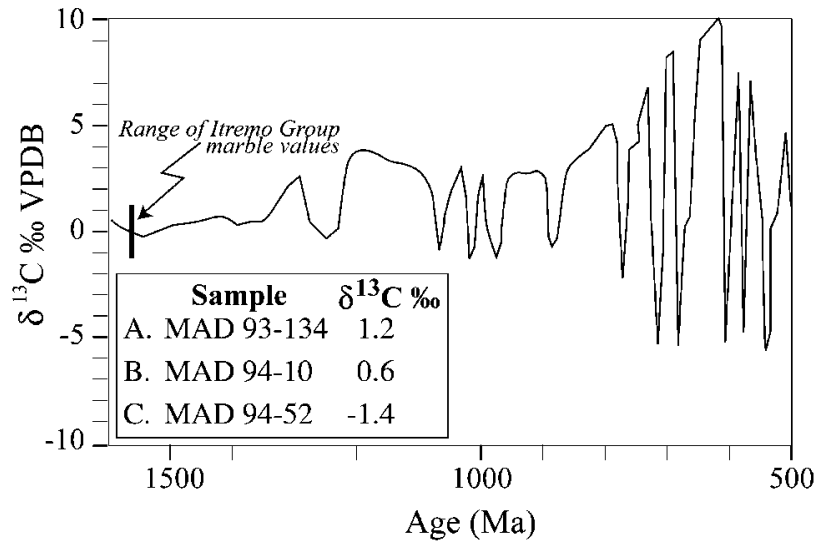

Figure 6. Carbon isotope values (data collected at USGS Menlo Park by L. D. White) for Itremo Group marbles compared with the global chemostratigraphic curve for marine (including stromatolitic) carbonates adapted from Kaufman (Kaufman 1997; Kah et al. 1999). See figure 1 for sample locations.

ages in the Irumide belt (Rainaud et al. 1999) and the Magondi belt in northern Zimbabwe (Munyanyiwa et al. 1994; Rainaud et al. 1999). This peak is small in figure $4 C$ because precise data thus far are few, but the probable significance of this age range in the African basement is indicated by a number of imprecise U-Pb ages around $1900 \mathrm{Ma}$ from the Ubendian belt in Tanzania (Lenoir et al. 1994) and the Zambezi belt in Zimbabwe (Hargrove et al. 2003), and $\mathrm{Pb}-\mathrm{Pb}$ ages of around $1970 \mathrm{Ma}$ from the Ubendian-Usagaran orogen in Malawi (Ring et al. 2002).

The family of detrital peaks at 2000-2250 Ma (fig. $4 A)$ also has potential African matches not identified elsewhere in nearby Gondwana. There are crystallization ages of 2000-2060 Ma in the Zambian Irumide belt (Rainaud et al. 1999) and Kasai shield (Key et al. 2001). Discordant zircons from the Ubendian belt (Lenoir et al. 1994) and sphenes and monazites from the Usagaran belt (Möller et al. 1995) also record these ages. There are no published U-Pb ages in the range 2100-2300 Ma, but $\mathrm{Pb}-\mathrm{Pb}$ crystallization ages of 2000-2200 Ma have recently been reported from the Ubendian belt (Ring et al. 2002). There are 2540-2560-Ma ages in the Congo craton (Key et al. 2001) and $\mathrm{Pb}-\mathrm{Pb}$ ages from ignimbrites indicate 2530-Ma igneous activity in Kenya (Pinna et al. 2000), matching ages seen both in the Madagascar basement and in the Itremo Group. The oldest prominent peak in the Itremo data, at $2690 \mathrm{Ma}$, has analogues in Tanzania (Borg and Krogh 1999; Muhongo et al. 2001; Kröner et al. 


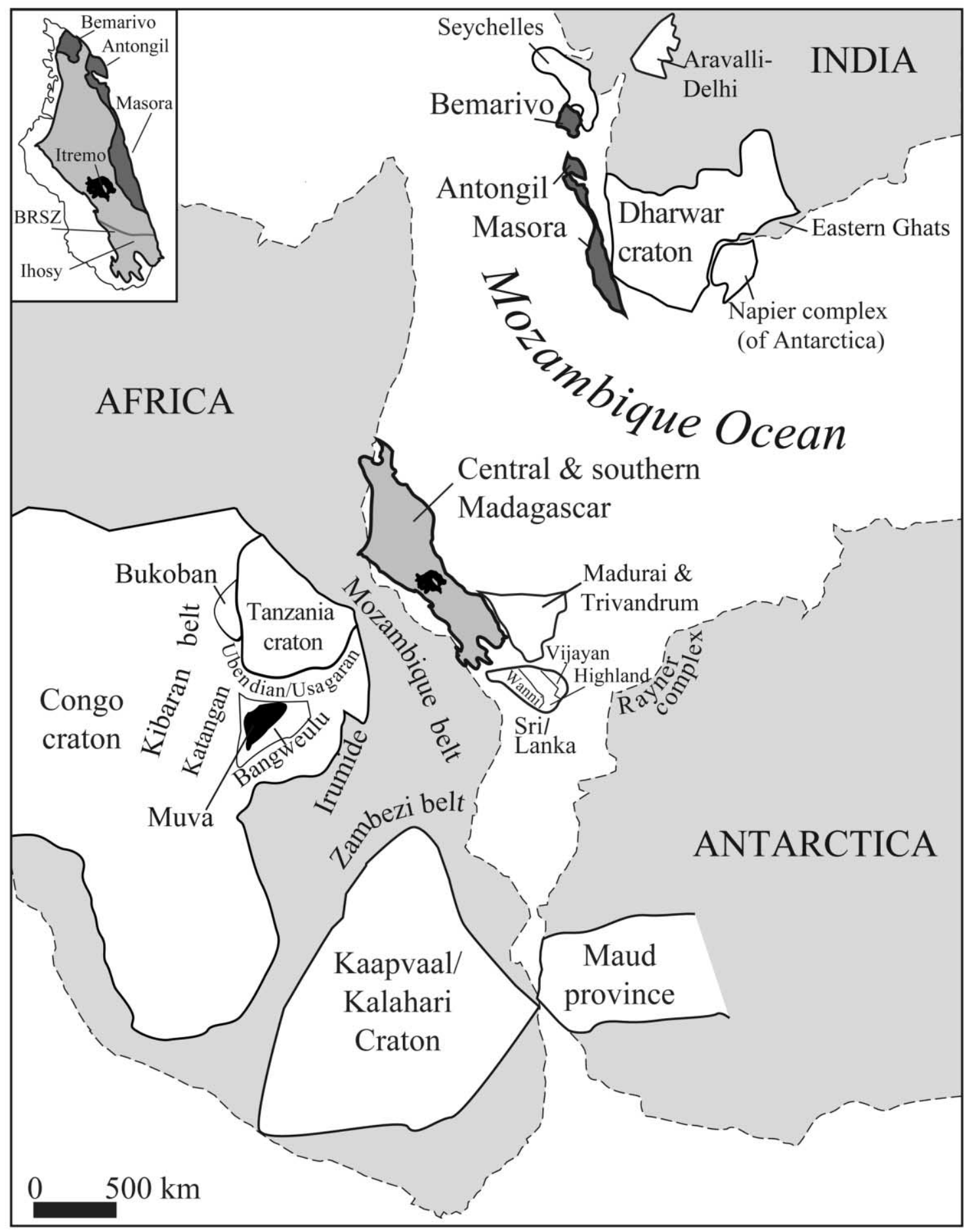

Figure 7. Proposed Proterozoic paleogeography of Madagascar and adjacent cratons about $750 \pm 50 \mathrm{Ma}$, showing relative locations of mobile belts and crustal blocks named in text. Inset shows components of Madagascar in current configuration. Reconstruction emphasizes that, whereas the eastern Madagascar provinces of Antongil and Masora were adjacent to the Dharwhar craton, central Madagascar (including the Itremo massif, shown in black), was adjacent to the Tanzania craton. This figure comes with several caveats. Separation distance between continental blocks is arbitrary and was probably substantially greater than shown. Details of terrane juxtaposition are not well constrained; for example, the fit among the Madurai, Sri Lanka, and Central Madagascar blocks is tentative. Sri Lanka is shown as a coherent block, but it is likely that the Vijayan complex was elsewhere at this time (see text). 
2003b; Reddy et al., in press; Sommer et al., in press). The African basement data set contains no ages greater than about $2800 \mathrm{Ma}$ (fig. 4C) and does not show any Paleoproterozoic or Archean populations that are not also seen in the Itremo Group, strengthening the argument that the Itremo Group was sourced from Africa.

The Dharwar craton of southern India is not a likely source for the Itremo Group clastic detritus because there is no trace in the Itremo data of the 2900-3000-Ma basement ages that are common in this region (fig. $4 D$ ). It is difficult to imagine that continental shelf sediment accumulating offshore of the Dharwar craton would fail to record such a prominent basement component. It is also notable that the $>3100-\mathrm{Ma}$ ages recorded from the Antongil and Masora blocks of northeastern Madagascar (Tucker et al. 1999b; Collins et al. 2003c) interpreted as part of the Dharwar craton (Tucker et al. 1999b; Collins and Windley 2002; de Wit 2003), are absent from the Itremo Group detrital zircons. Likewise, 1800-2200-Ma populations, prominent in the Itremo Group, have not been identified in the Dharwar craton.

The Madurai and Trivandrum blocks (fig. 7) are younger than the Dharwar craton (Yoshida et al. 1996; Santosh et al. 2003) and may be tectonically related to southern Madagascar (e.g., Meißner et al. 2002; Collins et al. 2003a). There are no published concordant $\mathrm{U}-\mathrm{Pb}$ data and no known matches for the Itremo Group detrital age peak at $1850 \mathrm{Ma}$, but $\mathrm{Nd}$ model ages for orthogneisses range from 2000 to $2600 \mathrm{Ma}$ (Yoshida et al. 1996), and protolith ages are reported as 2100-2400 Ma (Janardhan 1999); unpublished U-Pb zircon data (Ghosh 1999) indicate that the region experienced tectonothermal events at about $2900 \mathrm{Ma}, 2510-2540 \mathrm{Ma}$, and $2000 \mathrm{Ga}$. It is conceivable that the Madurai and Trivandrum blocks contributed some sediment to the Itremo Group.

Sri Lanka's potential as an Itremo Group source area is difficult to evaluate because of the lack of $\mathrm{U}-\mathrm{Pb}$ data from igneous rocks and orthogneisses, but a basement match to the 1970-Ma detrital peak is possible. There is a single precise 1950-Ma age, from the Digana orthogneiss (Baur et al. 1991), in addition to poorly characterized discordia data (MSWD values 2.4-5.5) that indicate intrusion ages of 1940-1850 Ma for Highland complex granitic gneisses (Baur et al. 1991; Hölzl et al. 1994); and Kröner et al. (2003a) suggest that the Highland complex might be related to the Ubendian belt. Consequently, (parts of) Sri Lanka cannot be excluded as a provenance candidate.

The East Antarctic basement consists of different terranes that were probably separate before the late Neoproterozoic (Wilson et al. 1997; Fitzsimons $2000 a, 2000 b$ ). The prominent basement age spike at $2500 \mathrm{Ma}$ (fig. $7 f$ ) represents the Napier complex in Enderby Land, interpreted as part of the Dharwar craton (Wilson et al. 1997; fig. 7). The data in aggregate lack ages in the range 1800-2100 Ma, making it unlikely that the Itremo Group had an East Antarctic sediment source.

Molo Group Provenance. Molo Group samples are overwhelmingly dominated by late Mesoproterozoic and Neoproterozoic ages between 630 and $1100 \mathrm{Ma}$ (fig. 4A). The substantial correspondence of populations among samples (fig. 3) indicates both that the identified populations are geologically meaningful and that the samples share a common provenance. The similarity of the grain populations between samples that are geographically separated (fig. 1) suggests substantial sediment mixing and homogenization of grains from different sources. Such mixing is unlikely to occur in local basins that tap small source areas and suggests a regionally integrated distal depocenter. If so, the rarity of older grains in the detrital population probably accurately records lack of older rocks in the regional source area.

Molo samples 1 and 2 share several age populations. The main difference between them is the presence of 630-Ma grains in sample 2, which may be due to differential fractionation during sediment transport; the pelitic protolith to sample 2 was undoubtedly much finer-grained than the sandstone of sample 1. Sample 3 shares populations with the other samples in addition to showing distinctly different, older provenance components (three individual grains with ages of $1446 \mathrm{Ma}, 2243 \mathrm{Ma}$, and $2586 \mathrm{Ma})$. These latter two grains match provenance populations in the Itremo Group, as does the 2927-Ma grain from sample 2 (fig. 3), but we cannot determine whether these grains were recycled from the Itremo Group or represent provenance overlap.

Madagascar has potential source rocks in the range 600-900 Ma (fig. 4B). However, although discordia upper-intercept ages of $956 \pm 40$ and $982 \pm 3 \mathrm{Ma}$ are recorded from the BongolavaRanotsara shear zone region in southern Madagascar (Müller 2000), no 1000-1100-Ma rocks are known, so a non-Malagasy source is required for that component of the Molo Group detritus. East Africa and Sri Lanka provide the best match; the concordance among the three highlighted Molo Group peaks, the largest Neoproterozoic east African basement peaks, and the Neoproterozoic Sri Lankan peaks is remarkable (fig. 4A, 4C, 4E) and strongly suggests source-sediment relationships. 
Basement ages from East Antarctica provide a possible although nonexact match for the 10001100-Ma detrital populations but are undersupplied in the younger populations. The Maud province, which was attached to the Kaapvaal/Kalahari craton in the Proterozoic (Fitzsimons 2000 $a$; Jacobs et al. 2003; fig. 7), has a distinct geochronologic signal dominated by Neoproterozoic events between 600$670 \mathrm{Ma}$ and 1000-1100 Ma (fig. 4F). The Rayner province provides the unshaded basement age spike at 900-1000 Ma (fig. 4F) but also includes a wide variety of older ages, most of which are absent from the Molo Group, so it is an unlikely source area.

Basement ages from the Dharwar craton provide no match to the Molo Group populations. Ages less than $1000 \mathrm{Ga}$ shown in figure $4 D$ come from the Aravalli-Delhi belt, which was probably far removed from the Molo Group depocenter (fig. 7). It is likely, however, that the Madurai and Trivandrum blocks have provenance potential because electron microprobe chemical dates from Madurai and Trivandrum block orthogneisses cluster around 800-1000 Ma (Santosh et al. 2003), and unpublished $\mathrm{U}-\mathrm{Pb}$ zircon ages indicate that this area experienced tectonothermal events at 800 and $600 \mathrm{Ma}$ (Ghosh 1999).

\section{Lithostratigraphic Correlations between Central Madagascar and Africa}

Itremo Group May Correlate with Zambian Muva Supergroup. The Muva Supergroup was deposited unconformably on Bangweulu and Ubendian basement (Daly and Unrug 1982; Ring et al. 2002) and appears to record a west-to-east facies transition from continental to shallow marine (Daly and Unrug 1982). The easternmost and stratigraphically uppermost Manganga and Manshya River Groups of the Muva Supergroup contain the same lithologies and suite of sedimentary structures as the shallow subaqueous clastic sediments of the Itremo Group, except that the Itremo Group contains a higher proportion of subaqueously deposited marine carbonate sediment.

We propose that the Itremo Group represents an offshore facies equivalent of the terrestrial-marine transition represented by the Muva Supergroup. The Muva Supergroup and Itremo Group may record a Paleoproterozoic cratonic margin sedimentary sequence representing the eastern coast of a pre-Gondwana continent. Rare, thin mafic volcanic flows occur in the Muva and Itremo Groups, but both have been interpreted as tectonically quiescent settings (Daly and Unrug 1982; Cox et al.
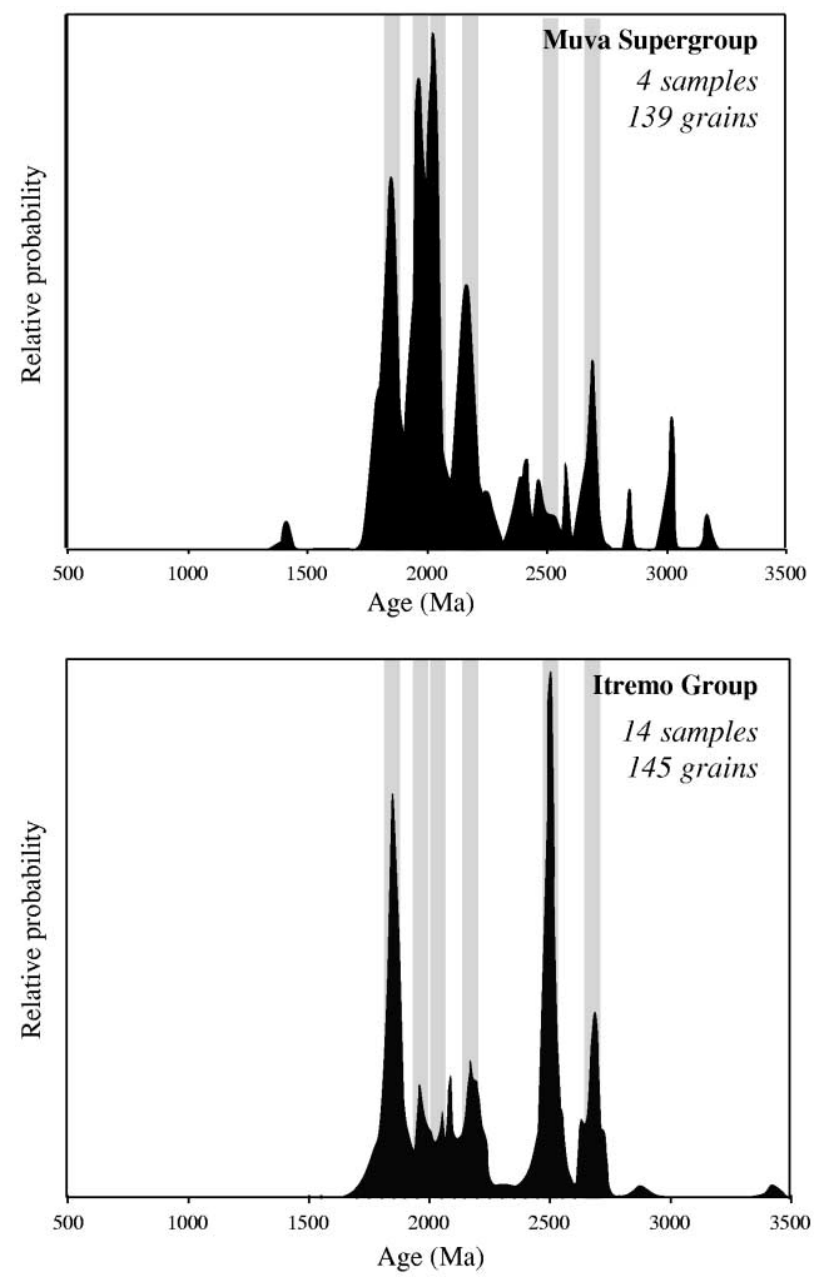

Figure 8. Age-probability curves for Muva Supergroup detrital zircons compared with Itremo Group data. Muva Supergroup data from Rainaud et al. (2003) and B. de Waele (unpublished data). Input parameters are ${ }^{207} \mathrm{~Pb} /$ ${ }^{206} \mathrm{~Pb}$ ages and $1 \sigma$ errors, and the exclusion probability is less than $5 \%$ for age groups comprising $2.5 \%$ or more of the Muva Group zircon population (see fig. 4 legend and table 3 for explanation).

1998), and they probably record passive margin sedimentation.

Muva Supergroup detrital zircon ages (Rainaud et al. 2003; B. de Waele, unpublished data) record many of the same age populations as the Itremo Group (fig. 8). The relative sizes of the age peaks differ, however, and there is much greater intersample age-population variation in the Muva Supergroup than in the Itremo Group. These observations are consistent with the more proximal setting of the Muva Supergroup, in which each locality represents a more restricted watershed and hence more source-rock variability in contrast to 

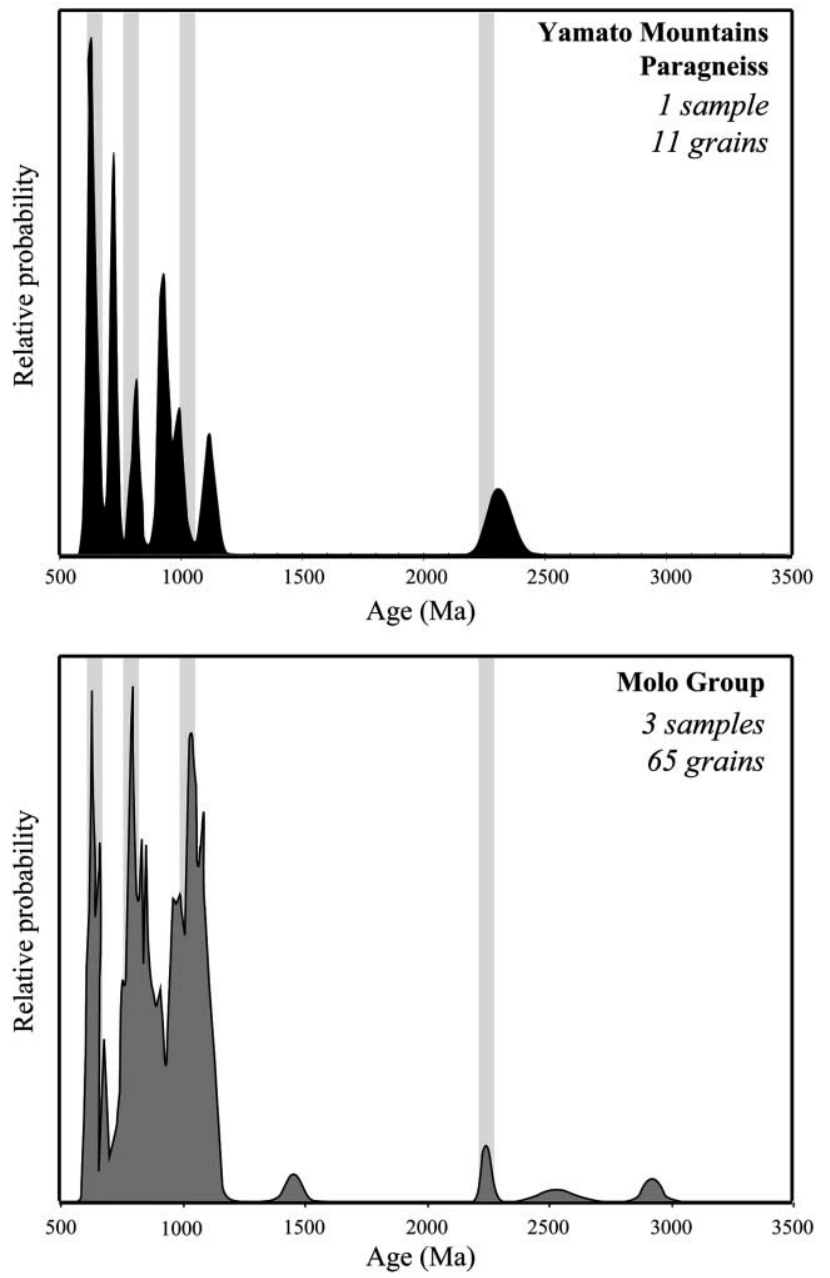

Figure 9. Age-probability curves for zircons from Yamato Mountains paragneiss (East Antarctica) compared with Molo Group populations. Yamato Mountains data from Shiraishi et al. (1994). Input parameters are ${ }^{238} \mathrm{U} /$ ${ }^{206} \mathrm{~Pb}$ ages and $1 \sigma$ errors.

the open-shelf environment and well-mixed sediment of the Itremo Group.

Molo Group May Correlate with Antarctic Paragneisses. Neoproterozoic sedimentary sequences in Africa, India, and Antarctica are poorly understood and generally also have weak age constraints. Aluminous paragneisses from the Yamato Mountains in East Antarctica provide a rare opportunity for detrital zircon age comparison and may correlate with the Molo Group. SHRIMP U/Pb zircon data from an orthopyroxene-biotite gneiss (Shiraishi et al. 1994) have age distributions suggestive of detrital populations (see fig. 9 in Shiraishi et al., 1994). Mixture modeling analysis of the U-Pb data produces age distributions that show substantial overlap with those of the Molo Group (table 4; fig.
9). We note that this comparison is based on very few data but suggest that it provides an interesting possibility.

Molo-age sequences are likely to be found elsewhere in related tectonic blocks. In Sri Lanka, metasediments in the Wanni Complex have age associations that suggest a Molo correlation (Kröner and Cordani, in press; Kröner et al. 2003a), and collection of detrital zircon data to test this hypothesis is in progress. There are no clear African correlatives to the Molo Group, but there are also very few age data for sedimentary sequences, so it is likely that this situation will change. It is tempting to correlate the Katangan Supergroup (fig. 7) with the Molo Group because the Katangan Supergroup overlies the Muva Group and was deposited sometime between 880 and $620 \mathrm{Ma}$ (Armstrong et al. 1999). However, lavas within the Katangan have been dated at approximately $765 \mathrm{Ma}$ (Key et al. 2001), indicating that the bulk of the sequence is older than the Molo Group, which was deposited between 613 and $553 \mathrm{Ma}$. The Bukoban System in Tanzania and related rocks (Tack 1995) may also be candidates for correlation with the Molo Group, but their precise age is not known.

\section{Critique of Paleogeographic Models for Madagascar}

Madagascar's position in reconstructions of preGondwana continental configurations varies. Dalziel (1991) placed Madagascar against east Africa, but on subsequent revision (Dalziel 1997) moved it next to India. Hoffman (1991) located Madagascar against Dronning Maud Land, East Antarctica, based in part on interpretation of Madagascar as a Grenvillian-age (900-1100 Ma) mobile belt, which later geochronologic work showed not to be the case. Subsequent workers therefore modified his figure by locating Madagascar alongside India (e.g., Fitzsimons 2000a) or excluding it entirely (e.g., Boger et al. 2000). The majority of reconstructions place Madagascar conservatively next to India in the Neoproterozoic along a western continental edge (Moores 1991; Dalziel 1997; Weil et al. 1998; Dalziel et al. 2000; Meert 2001; Torsvik 2003), although this placement has been questioned (Kröner et al. 2000; Kröner 2002). The recently published configuration for proposed supercontinent Columbia (Rogers and Santosh 2002) locates Madagascar at $1.5 \mathrm{Ga}$ in an interior position between India and parts of Africa (Zimbabwe and Kalahari cratons).

We disagree with existing paleogeographic reconstructions for three reasons. (1) Central Madagascar must have been near the Tanzania craton and dis- 
tant from the Dharwar craton in the Paleoproterozoic because the Itremo massif area was receiving sediment from east Africa but not from the midArchean rocks of India. The Columbia reconstruction in which Madagascar unites the two halves of "expanded Ur" at 1.5 Ga (Rogers and Santosh 2002) therefore cannot work. (2) Neoproterozoic reconstructions that place Madagascar squarely next to India are also questionable because given a Paleoproterozoic connection with the Tanzania craton, there is no geologic evidence to suggest that Madagascar rifted from Africa, collided with India, and then collided back with Africa in the Neoproterozoic. It seems reasonable that central Madagascar and Tanzania remained connected and participated together in the tectonic events of the Neoproterozoic. In addition, the Molo Group data do not suggest Neoproterozoic sediment contribution from the Dharwar craton. (3) Published reconstructions summarized above have in common that Madagascar is represented as a coherent block in the Meso- and Neoproterozoic. In fact, there is ample evidence that Madagascar consists of at least two and possibly more distinct terranes (Kröner et al. 2000; Collins and Windley 2002; Collins et al. $2003 c$.

Southern Madagascar consists mostly of Mesoto Paleoproterozoic crust with some late Archean material heavily reworked in the Neoproterozoic (de Wit et al. 2001). It has been proposed that southern Madagascar is a distinct terrane that collided with central Madagascar along the BongolavaRanotsara shear zone (Müller 2000), but the lack of geochronologic distinctions between the basement in central and southern Madagascar (de Wit et al. 2001; de Wit 2003) and the apparent detrital grain similarities discussed above between the central Madagascar metasediments (tables 3, 4) and those at Ihosy (Kröner et al. 1996) indicate that central and southern Madagascar were linked throughout the Proterozoic.

We propose that central and southern Madagascar were attached to the Tanzanian craton in the Proterozoic, while northern and eastern Madagascar were part of India (fig. 7). There are strong geochronologic and lithologic similarities between the Antongil block of Madagascar and the Dharwar craton of India (Tucker et al. 1999b; Collins and Windley 2002; Paquette et al. 2003; Collins et al. 2003c), but our data clearly link central Madagascar to African basement rocks. De Wit (2003) also presents a model in which parts of Madagascar were on either side of the Mozambique Ocean, but his model includes the possibility of central Madagascar connected to India (see his fig. 6 and p. 224), whereas we stress that only the slivers of the Antongil and Masora blocks in northern and eastern Madagascar were attached to the Dharwar craton.

\section{A Model for Madagascar Assembly Based on Sediment Provenance Constraints}

In the Paleoproterozoic, during Itremo Group deposition, central Madagascar and surrounding areas (of undefined extent) were contiguous with the Tanzania craton (fig. 7). The Itremo Group and the probably coeval Muva Supergroup in Zambia together may represent an eastward-thickening clastic wedge developed on the eastern passive margin of the Tanzania craton. Sri Lanka (or part thereof) and the Madurai/Trivandrum blocks may have been attached, but the Dharwar craton was not. The East Antarctic Maud, Rayner, and Napier provinces likewise were probably elsewhere. The Antongil and Masora blocks were separate from central Madagascar and probably attached to India on the far side of the Mozambique ocean (Tucker et al. 1999a; Collins et al. 2003c).

There is no published record in the Malagasy basement of the 1000-1100-Ma Kibaran/Grenvillian events, widespread in Africa and East Antarctica, that are interpreted as suturing the supercontinent Rodinia (Wilson et al. 1997; Fitzsimons $2000 a$ ), and these ages are rare or absent in eastern Tanzania (Kröner 2002; Kröner et al. 2003b). The Tanzania craton/Madagascar Paleoproterozoic passive margin may therefore have persisted as an exterior passive margin with Kibaran accretionary events restricted to the west and south of Madagascar, for example, in present-day Zambia and Mozambique and in the Kibaran belt between the Tanzania and Congo cratons where $\sim 1-\mathrm{Ga}$ ages are well documented (e.g., Romer and Lehmann 1995; Manhica et al. 2001; De Waele et al. 2003). Most reconstructions, including the most recent (Torsvik 2003), show Tanzania in an external position on the western edge of Rodinia at $750 \mathrm{Ma}$, so our model represents only a slight modification in overall Rodinia paleogeography.

Central Madagascar experienced extensive bimodal magmatism at $780-800 \mathrm{Ma}$ as a continental magmatic arc developed (Handke et al. 1999), and this has been correlated with magmatic activity in Sri Lanka based on chemistry and age (Kröner et al. 2000, 2003a). Somewhat younger provinces in the Seychelles ( 750 Ma; Ashwal et al. 2002) and the Bemarivo block of northern Madagascar ( 715$750 \mathrm{Ma}$; Tucker et al. 1999a; Buchwaldt and Tucker 2001) may represent a companion arc on the opposite side of the Mozambique ocean. 
Subsequent to arc magmatism, the 750-620-Ma East African Orogen (Stern 1994; Meert 2003) is not strongly represented in Madagascar. There is evidence in southern (but not central) Madagascar for high-grade metamorphism at about $650 \mathrm{Ma}$ and for magmatism and polyphase crustal shortening at 650-608 Ma (de Wit et al. 2001; de Wit 2003). Stratoid granitic plutons were emplaced in central Madagascar at about $630 \mathrm{Ma}$ (Paquette and Nédélec 1998). Data from the Bemarivo block (Buchwaldt and Tucker 2001; Buchwaldt et al. 2003) do not include any 600-700-Ma ages. We therefore infer that the components of Madagascar were still separated at this time and that the East African Orogen does not involve collision of Africa/southern Madagascar with Dharwar/northeastern Madagascar.

The East African Orogen in Madagascar may mark collision of the Tanzanian craton plus Madagascar (plus Sri Lanka?) with the Maud province of Antarctica. This is supported by recent data indicating peak granulite facies metamorphism in Tanzania at about 630-640 Ma (Maboko 2001; Kröner et al. 2003b; Sommer et al., in press). Because the Maud province was part of the Kalahari craton (Arndt et al. 1991; Wilson et al. 1997; Jacobs et al. 1998), this would represent collision of the Tanzanian/Congo and Kalahari cratons, as proposed by De Waele et al. (2003), and agreement with the observations made by Meert (2003), although differing in the interpretation. The outboard (eastern) edge of Madagascar would not have collided, consistent with 650-Ma high-grade metamorphism in southern but not central Madagascar. Sri Lanka was probably involved in this collision because it has a strong 550-600-Ma thermal overprint (Kröner et al. 2003a). It is possible that Sri Lanka was in fact assembled during this time; increasing data suggest that the largely 880-1100 Ma Vijayan complex was part of the Dronning Maud Land-Lützow Holm belt (Kröner et al. 2003a, whereas the Wanni complex may have been connected to northern Mozambique (Kröner et al. 2001).

After the East African Orogen, erosion of the newly exposed basement, including the 800-Ma rocks of the Andean arc phase and uplifted, tectonically transported 1000-1100-Ma Kibaran/Grenvillian rocks, generated sediment that was deposited to form the Molo Group and possible Antarctic correlative units.

The entire island of Madagascar records orogeny at $570-530 \mathrm{Ma}$ (see compilation in Meert 2003), which we therefore propose represents the amalgamation of north and central/southern Madagascar during the culminating phase(s) of Gondwana assembly. Metamorphic rims on detrital zircon in both the Itremo and Molo Groups formed at $556 \pm 10 \mathrm{Ma}$ (Cox et al. 2001; R. Cox, unpublished data), and intense regional deformation in central Madagascar occurred at 560-530 Ma (Nédélec et al. 2000; Collins et al. 2003b; Goncalves et al. 2003). Peak metamorphism along the BongolavaRanotsara shear zone, interpreted to be coincident with movement, is dated at $547 \pm 6 \mathrm{Ma}$, and movement had ceased by about $530 \mathrm{Ma}$, based on the age of stitching intrusions (Müller 2000). Regional metamorphism is estimated at about $520 \mathrm{Ma}$ in northern and eastern Madagascar (Buchwaldt and Tucker 2001; Buchwaldt et al. 2003) and in southern Madagascar at 500-590 Ma (Martelat et al. 2000) and 520-605 Ma (de Wit et al. 2001). The broad range of metamorphic estimates probably reflects both the complexity of the orogenic episode and the reconnaissance nature of most of the geochronology. During this interval, the Dharwar craton of India plus the Antongil block of Madagascar (Collins and Windley 2002) probably collided with central Madagascar as the easternmost edge of the Tanzania/Kalahari/Sri Lanka/East Antarctica assemblage. The assembly may have taken place along the Betsimisaraka suture of Collins and Windley (2002).

\section{Conclusions}

The Itremo Group of central Madagascar is Paleoproterozoic in age, probably deposited sometime in the interval 1600-1700 Ma. The Neoproterozoic Molo Group was deposited between 623 and 553 Ma. Within the constraints of the published geochronology for the potential source regions, detrital zircon data demonstrate no sediment-source relationship between central Madagascar and the Dharwar craton, and the data indicate that central and southern Madagascar were adjacent to east Africa in the Proterozoic. The detrital zircon data support a model for final Gondwana assembly in which the suture is drawn through Madagascar (Wilson et al. 1997; Jacobs et al. 1998; Collins and Windley 2002), separating a western province (Kalahari and Tanzanian cratons plus south and central Madagascar, Sri Lanka, Dronning Maud Land-Lützow Holm belt, and the Trivandrum and Madurai Blocks) from an eastern province (Dharwar craton plus northern and eastern Madagascar, Napier Complex, and points east in Antarctica). The data also suggest that assembly of the western province was polyphase. 


\section{A C K N O W LED G M E N T S}

This research was supported by National Science Foundation grant EAR-9814945 to R. Cox. A. Kröner thanks the German Science Foundation (DFG) for financial support during fieldwork and SHRIMP dating. Thanks also to K. Gallagher (Imperial College) for providing the program MIX, and especially for his help with numerous technical problems; K. Ludwig of the Berkeley Geochronology Center for supplying Isoplot/Ex; L. D. White of the USGS at Menlo Park for the carbon isotope analyses; J. Sparks at Boston University for his help with sample preparation; and J. Meert (University of Florida) and J. Rogers (University of North Carolina) for their thoughtful reviews. A. S. Collins's and B. De Waele's contributions form Tectonics Special Research Centre publication 243.

\section{R E F E R E N C E S C I T E D}

Anbar, A. D., and Knoll, A. H. 2002. Proterozoic ocean chemistry and evolution: a bioinorganic bridge? Science 297:1137-1142.

Armstrong, R. A.; Robb, L. J.; Master, S.; Kruger, F. J.; and Mumba, P. A. C. C. 1999. New U-Pb age constraints on the Katangan Sequence, Central African Copperbelt. J. Afr. Earth Sci. 28:6-7.

Arndt, N. R.; Todt, W.; Chauvel, C.; Tapfer, M.; and Weber, K. 1991. U-Pb zircon age and $\mathrm{Nd}$ isotopic composition of granitoids, charnockites and supracrustal rocks from Heimefrontfjella, Antarctica. Geol. Rundsch. 80:759-777.

Ashwal, L. D.; Demaiffe, D.; and Torsvik, T. H. 2002. Petrogenesis of Neoproterozoic granitoids and related rocks from the Seychelles: the case for an Andeantype arc origin. J. Petrol. 43:45-83.

Baur, N.; Kröner, A.; Liew, T. C.; Todt, W.; Williams, I. S.; and Hofmann, A. W. 1991. U-Pb isotopic systematics of zircons from prograde and retrograde transition zones in high-grade orthogneisses, Sri Lanka. J. Geol. 99:527-545.

Bodorkos, S.; Cawood, P. A.; Oliver, N. H. S.; and Nemchin, A. A. 2000. Rapidity of orogenesis in the Paleoproterozoic Halls Creek Orogen, northern Australia: evidence from SHRIMP zircon data, CL zircon images, and mixture modeling studies. Am. J. Sci. 300:60-82.

Boger, S. D.; Carson, C. J.; Wilson, C. J. L.; and Fanning, C. M. 2000. Neoproterozoic deformation in the Radok Lake region of the northern Prince Charles Mountains, east Antarctica; evidence for a single protracted metamorphic event. Precambrian Res. 104:1-24.

Borg, G., and Krogh, T. E. 1999. Isotopic age data of single zircons from the Archaean Sukumaland Greenstone Belt, Tanzania. J. Afr. Earth Sci. 29:301-312.

Buchwaldt, R., and Tucker, R. D. 2001. P-T-Time constraints on the metamorphic rocks of north Madagascar and their relevance on the assembly of Gondwanaland. Geol. Soc. Am. Abstr. Program 33:A436.

Buchwaldt, R.; Tucker, R. D.; and Dymek, R. F. 2003. Geothermobarometry and U-Pb geochronology of metapelitic granulites and pelitic migmatites from the Lokoho region, northern Madagascar. Am. Mineralogist 88:1753-1768.

Cawood, P. A.; Nemchin, A. A.; Leverenz, A.; Saeed, A.; and Ballance, P. F. 1999. U/Pb dating of detrital zir- cons: implications for the provenance record of Gondwana margin terranes. Geology 111:1107-1119.

Collins, A. S.; Fitzsimons, I. C. W.; Hulscher, B.; and Razakamanana, T. 2003a. Structure of the eastern margin of the East African Orogen in central Madagascar. Precambrian Res. 123:111-133.

Collins, A. S.; Johnson, S.; Fitzsimons, I. C. W.; Powell, C. M.; Hulscher, B.; Abello, J.; and Razakamanana, T. 2003b. Neoproterozoic deformation in central Madagascar: a structural section through part of the East African Orogen. In Powell, C. M., ed. Proterozoic East Gondwana: supercontinent assembly and breakup. Geol. Soc. Lond. Spec. Publ. 206:363-379.

Collins, A. S.; Kröner, A.; Fitzsimons, I. C. W.; and Razakamanana, T. 2003c. Detrital footprint of the Mozambique Ocean: $\mathrm{U} / \mathrm{Pb}$ SHRIMP and $\mathrm{Pb}$ evaporation zircon geochronology of metasedimentary gneisses in eastern Madagascar. Tectonophysics 375:77-99.

Collins, A. S.; Razakamanana, T.; and Windley, B. F. 2000. Neoproterozoic extensional detachment in central Madagascar: implications for the collapse of the East African Orogen. Geol. Mag. 137:39-51.

Collins, A. S., and Windley, B. F. 2002. The tectonic evolution of central and northern Madagascar and its place in the final assembly of Gondwana. J. Geol. 110: 325-340.

Cox, R.; Armstrong, R. A.; and Ashwal, L. D. 1998. Geology of the Proterozoic Itremo Group, central Madagascar, and implications for pre-Gondwana paleogeography. J. Geol. Soc. Lond. 155:1009-1024.

Cox, R.; Coleman, D. S.; Wooden, J. L.; and DeOreo, S. B. 2001. A newly-recognised Late Neoproterozoic metasedimentary sequence in central Madagascar suggests terrane juxtaposition at $560 \pm 7 \mathrm{Ma}$ during Gondwana assembly. Geol. Soc. Am. Abstr. Program 33:A436.

Daly, M. C., and Unrug, R. 1982. The Muva Supergroup of northern Zambia: a craton to mobile belt sedimentary sequence. Trans. Geol. Soc. S. Afr. 85:155-165.

Dalziel, I. W. D. 1991. Pacific margins of Laurentia and East Antarctica-Australia as a conjugate rift pair: evidence and implications for an Eocambrian supercontinent. Geology 19:598-601.

— . 1997. Neoproterozoic-Paleozoic geography and tectonics: review, hypothesis, environmental speculation. Geol. Soc. Am. Bull. 109:16-42. 
Dalziel, I. W. D.; Mosher, S.; and Gahagan, L. M. 2000. Laurentia-Kalahari collision and the assembly of Rodinia. J. Geol. 108:499-513.

Daso, A. A. H. 1986. Géologie d'une plateforme carbonatée metamorphique: Valée de la Sahatany, centre de Madagascar: etude structurale pétrographique et géochimique. Thèse de doctorat, Université Paul Sabatier, Toulouse, $202 \mathrm{p}$.

De Waele, B., and Mapani, B. 2002. Geology and correlation of the central Irumide Belt. J. Afr. Earth Sci. 35: 385-397.

De Waele, B.; Wingate, M. T. D.; Fitzsimons, I. C. W.; and Mapani, B. S. E. 2003. Untying the Kibaran knot: a re-assessment of Mesoproterozoic correlations in southern Africa based on SHRIMP U-Pb data from the Irumide belt. Geology 31:509-512.

de Wit, M. J. 2003. Madagascar: heads it's a continent, tails it's an island. Annu. Rev. Earth Planet. Sci. 31: 213-248.

de Wit, M. J.; Bowring, S. A.; Ashwal, L. D.; Randrianasolo, L. G.; Morel, V. P. I.; and Rambeloson, R. A. 2001. Age and tectonic evolution of Neoproterozoic ductile shear zones in southwestern Madagascar, with implications for Gondwana studies. Tectonics 20:1-45.

Dodson, M. H.; Compston, W.; Williams, I. S.; and Wilson, J. F. 1988. A search for ancient detrital zircons in Zimbabwean sediments. J. Geol. Soc. Lond. 145:977983.

Fernandez, A., and Schreurs, G. 2003. Tectonic evolution of the Proterozoic Itremo Group metasediments in central Madagascar. In Dasgupta, S., ed. Proterozoic East Gondwana: supercontinent assembly and breakup. Geol. Soc. Lond. Spec. Publ. 206:381-399.

Fernandez, A.; Schreurs, G.; Villa, I. M.; Huber, S.; and Rakotondrazafy, M. 2003. Age constraints on the tectonic evolution of the Itremo region in central Madagascar. Precambrian Res. 123:87-110.

Fitzsimons, I. C. W. 2000a. Grenville-age basement provinces in East Antarctica: evidence for three separate collisional orogens. Geology 28:879-882.

- 2000b. A review of tectonic events in the East Antarctic Shield and their implications for Gondwana and earlier supercontinents. J. Afr. Earth Sci. 31:3-23.

Ghosh, J. G. 1999. U-Pb geochronology and structural geology across major shear zones of the Southern Granulite Terrain of India and organic carbon stratigraphy of the Gondwana coal basins of India. Ph.D. thesis, University of Cape Town.

Goncalves, P.; Nicollet, C.; and Lardeaux, J.-M. 2003. Finite strain pattern in Andriamena unit (north-central Madagascar): evidence for Late NeoproterozoicCambrian thrusting during continental convergence. Precambrian Res. 123:135-157.

Handke, M. J. 2001. Neoproterozoic magmatism in the Itremo region, central Madagascar: geochronology, geochemistry, and petrogenesis. Ph.D. thesis, Washington University, $517 \mathrm{p}$.

Handke, M. J.; Tucker, R. D.; and Ashwal, L. D. 1999. Neoproterozoic continental arc magmatism in westcentral Madagascar. Geology 27:351-354.
Hargrove, U. S.; Hanson, R. E.; Martin, M. W.; Blenkinsop, T. G.; Bowring, S. A.; Walker, N. W.; and Munyanyiwa, H. 2003. Tectonic evolution of the Zambezi orogenic belt: geochronological, structural, and petrological constraints from northern Zimbabwe. Precambrian Res. 123:159-186.

Hoffman, P. F. 1991 Did the breakout of Laurentia turn Gondwanaland inside-out? Science 252:1409-1412.

Hofmann, H. J. 1987. Precambrian biostratigraphy. Geoscience Canada 14:135-154.

Hofmann, H. J., and Jackson, G. D. 1987. Proterozoic ministromatolites with radial-fibrous fabric. Sedimentology 34:963-971.

Hölzl, S.; Hofmann, A. W.; Todt, W.; and Köhler, H. 1994. $\mathrm{U}-\mathrm{Pb}$ geochronology of the Sri Lankan basement. Precambrian Res. 66:123-149.

Jacobs, J.; Fanning, C. M.; and Bauer, W. 2003. Timing of Grenville-age vs. Pan-African medium- to high-grade metamorphism in western Dronning Maud Land (East Antarctica) and significance for correlations in Rodinia and Gondwana. Precambrian Res. 125:1-20.

Jacobs, J.; Fanning, C. M.; Henjes-Kunst, F.; Olesch, M.; and Paech, H.-J. 1998. Continuation of the Mozambique Belt into East Antarctica: Grenville-age metamorphism and polyphase Pan-African high-grade events in central Dronning Maud Land. J. Geol. 106: 385-406.

James, N. P., and Narbonne, G. M. 2002. Proterozoic reef evolution. Geol. Soc. Am. Abstr. Program 34:64.

Janardhan, A. S. 1999. Southern granulite terrain, south of the Palghat-Cauvery shear zone: implications for India-Madagascar connection. Gondwana Res. 2:463469.

Kah, L. C.; Sherman, A. G.; Narbonne, G. M.; Knoll, A. H.; and Kaufman, A. J. 1999. $\delta^{13} \mathrm{C}$ stratigraphy of the Proterozoic Bylot Supergroup, Baffin Island, Canada: implications for regional lithostratigraphic correlations. Can. J. Earth Sci. 36:313-332.

Kaufman, A. J. 1997. An ice age in the tropics. Science 386:227-229.

Key, R. M.; Liyungu, A. K.; Njamu, F. M.; Somwe, V.; Banda, J.; Mosley, P. N.; and Armstrong, R. A. 2001. The western arm of the Lufilian Arc in NW Zambia and its potential for copper mineralization. J. Afr. Earth Sci. 33:503-528.

Kröner, A. 2002. The Mozambique belt of East Africa and Madagascar: significance of zircon and $\mathrm{Nd}$ model ages for Rodinia and Gondwana supercontinent formation and dispersal. S. Afr. J. Geol. 105:151-166.

Kröner, A.; Braun, I.; and Jaeckel, P. 1996. Zircon geochronology of anatectic melts and residues from a high-grade pelitic assemblage at Ihosy, southern Madagascar: evidence for Pan-African granulite metamorphism. Geol. Mag. 133:311-323.

Kröner, A., and Cordani, U. 2003. African, southern Indian and South American cratons were not part of the Rodinia supercontinent: evidence from field relationships and geochronology. Tectonophysics 375:325352.

Kröner, A.; Hegner, E.; Windley, B. F.; Collins, A. S.; 
Brewer, T. S.; Razakamanana, T.; and Pidgeon, R. S. 2000. Age and magmatic history of the Antananarivo Block, central Madagascar, as derived from zircon geochronology and $\mathrm{Nd}$ isotope systematics. Am. J. Sci. 300:251-288.

Kröner, A.; Kehelpannala, K. V. W.; and Hegner, E. $2003 a$. Ca. 750-1100 Ma magmatic events and Grenville-age deformation in Sri Lanka: relevance for Rodinia Supercontinent formation and dispersal, and Gondwana amalgamation. J. Asian Earth Sci. 22:279-300.

Kröner, A.; Muhongo, S.; Hegner, E.; and Wingate, M. T. D. 2003b. Single zircon geochronology and Nd isotopic systematics of Proterozoic high-grade rocks from the Mozambique belt of southern Tanzania (Masasi area): implications for Gondwana assembly. J. Geol. Soc. Lond. 160:1-13.

Kröner, A.; Willner, A. P.; Hegner, E.; Jaeckel, P.; and Nemchin, A. A. 2001. Single zircon ages, PT evolution and $\mathrm{Nd}$ isotopic systematics of high-grade gneisses in southern Malawi and their bearing on the extent of the Mozambique belt into southern Africa. Precambrian Res. 109:257-291.

Kröner, A.; Windley, B. F.; Jaeckel, P.; Brewer, T. S.; and Razakamanana, T. 1999. New zircon ages and regional significance for the evolution of the Pan-African orogen in Madagascar. J. Geol. Soc. Lond. 156:11251135.

Lenoir, J. L.; Liégeois, J.-P.; Theunissen, K.; and Klerkx, J. 1994. The Palaeoproterozoic Ubendian shear belt in Tanzania: geochronology and structure. J. Afr. Earth Sci. 19:169-184.

Maboko, M. A. H. 2001. Dating post-metamorphic cooling of the eastern granulites in the Mozambique belt of northern Tanzania using the garnet Sm-Nd method. Gondwana Res. 4:329-336.

Manhica, A. D. S. T.; Grantham, G. H.; Armstrong, R. A.; Guise, P. G.; and Kruger, F. J. 2001. Polyphase deformation and metamorphism at the Kalahari CratonMozambique Belt boundary. In Hand, M., ed. Continental reactivation and reworking. Geol. Soc. Lond. Spec. Publ. 184:303-322.

Martelat, J.-E.; Lardeaux, J.-M.; Nicollet, C.; and Rakotondrazafy, R. 2000. Strain pattern and late Precambrian deformation history in southern Madagascar. Precambrian Res. 102:1-20.

Meert, J. G. 2001. Growing Gondwana and rethinking Rodinia: a paleomagnetic perspective. Gondwana Res. 4:279-288.

-2003. A synopsis of events related to the assembly of eastern Gondwana. Tectonophysics 362:1-40.

Meißner, B.; Deters, P.; Srikantappa, C.; and Köhler, H. 2002. Geochronological evolution of the Moyar, Bhavani and Palghat shear zones of southern India: implications for east Gondwana correlations. Precambrian Res. 114:149-175.

Moine, B. 1968. Massif schisto-quartzo-dolomitique: région d'Ambatofinandrahana centre-ouest du socle cristallin Précambrien de Madagascar. Centre de 1'Institut Géographique National, Tananarive. Scale, $1: 200,000$.
1974. Caractères de sédimentation et de métamorphisme de séries précambriennes épizonales à catazonales du centre de Madagascar (Région d'Ambatofinandrahana). Université Nancy, Sciences de la Terre Mémoire 31, 293 p.

Möller, A.; Appel, P.; Mezger, K.; and Schenk, V. 1995. Evidence for a 2 Ga subduction zone: eclogites in the Usagaran belt of Tanzania. Geology 23:1067-1070.

Moores, E. M. 1991. Southwest U.S.-East Antarctic (SWEAT) connection: a hypothesis. Geology 19:425428.

Muhongo, S.; Kröner, A.; and Nemchin, A. A. 2001. Single zircon evaporation and SHRIMP ages for granulite facies rocks in the Mozambique belt of Tanzania. J. Geol. 109:171-189.

Müller, B. 2000. The evolution and significance of the Bongolova-Ranotsara shear zone, Madagascar. Ph.D. thesis, Rand Afrikaans University, $126 \mathrm{p}$.

Munyanyiwa, H.; Kröner, A.; and Jaeckel, P. 1994. U-Pb and $\mathrm{Pb}-\mathrm{Pb}$ single zircon ages for charno-enderbites from the Magondi mobile belt, northwest Zimbabwe. S. Afr. J. Geol. 98:52-57.

Nédélec, A.; Ralison, B.; Bouchez, J.-L.; and Grégoire, V. 2000. Structure and metamorphism of the granitic basement around Antananarivo: a key to the PanAfrican history of central Madagascar and its Gondwana connections. Tectonics 19:997-1020.

Ngoyi, K., and Dejonghe, L. 1995. Geologie et genese du gisement stratoide cuprifere de Kinsenda (SE du Shaba, Zaire). Bull. Soc. Belge Geol. 104:245-281.

Olcott, A.; Corsetti, F.; and Awramik, S. M. 2002. A new look at stromatolite form diversity. Geol. Soc. Am. Abstr. Program 34:271.

Paquette, J. L.; Moine, B.; and Rakotondrazafy, M. 2003. ID-TIMS using the step-wise dissolution technique versus ion microprobe U-Pb dating of metamict Archean zircons from NE Madagascar. Precambrian Res. 121:73-84.

Paquette, J. L., and Nédélec, A. 1998. A new insight into Pan-African tectonics in the East-West Gondwana collision zone by $\mathrm{U}-\mathrm{Pb}$ zircon dating of granites from central Madagascar. Earth Planet. Sci. Lett. 155:4556.

Pinna, P.; Cocherie, A.; Thiéblemont, D.; and Jezequel, P. 2000. The Kisii Group of western Kenya: an endArchaean (2.53 Ga) late orogenic volcano sedimentary sequence. J. Afr. Earth Sci. 30:79-97.

Rainaud, C.; Armstrong, R. A.; Master, S.; and Robb, L. J. 1999. A fertile Palaeoproterozoic magmatic arc beneath the Central African Copperbelt. In Stanley, C. J., ed. Mineral deposits: processes to processing. London, Balkema, p. 1427-1430.

Rainaud, C.; Master, S.; Armstrong, R. A.; and Robb, L. J. 2003. A cryptic Mesoarchaean terrane in the basement to the Central African Copperbelt. J. Geol. Soc. Lond. 160:11-14.

Raoelison, I. L. 1997. Structure and metamorphism of the Itremo Group, central Madagascar. Master's thesis, Rand Afrikaans University, $188 \mathrm{p}$.

Reddy, S. M.; Collins, A. S.; and Mruma, A. 2003. Com- 
plex high-strain deformation in the Usagaran Orogen, Tanzania: structural setting of Palaeoproterozoic eclogites. Tectonophysics 375:101-123.

Ring, U.; Kröner, A.; Buchwaldt, R.; Toulkeridis, T.; and Layer, P. W. 2002. Shear-zone patterns and eclogitefacies metamorphism in the Mozambique belt of northern Malawi, east-central Africa: implications for the assembly of Gondwana. Precambrian Res. 116:1956.

Rogers, J. J. W., and Santosh, M. 2002. Configuration of Columbia, a Mesoproterozoic supercontinent. Gondwana Res. 5:5-22.

Romer, R. L., and Lehmann, B. 1995. U-Pb Columbite age of Neoproterozoic $\mathrm{Ta}-\mathrm{Nb}$ mineralization in $\mathrm{Bu}-$ rundi. Econ. Geol. 90:2303-2309.

Sambridge, M. S., and Compston, W. 1994. Mixture modeling of multi-component data sets with application to ion-probe zircon ages. Earth Planet. Sci. Lett. 128: 373-390.

Santosh, M.; Yokoyama, K.; Biju-Sekhar, S.; and Rogers, J. J. W. 2003. Multiple tectonothermal events in the granulite blocks of southern India revealed from EPMA dating: implications on the history of supercontinents. Gondwana Res. 6:29-63.

Shiraishi, K.; Ellis, D. J.; Hiroi, Y.; Fanning, C. M.; Motoyoshi, Y.; and Nakai, Y. 1994. Cambrian orogenic belt in East Antarctica and Sri Lanka: implications for Gondwana assembly. J. Geol. 102:47-65.

Sircombe, K. N. 2000a. Quantitative comparison of large sets of geochronological data using multivariate analysis: a provenance study example from Australia. Geochim. Cosmochim. Acta 64:1593-1616.

- 2000b. The usefulness and limitations of binned frequency histograms and probability density distributions for displaying absolute age data. Geol. Surv. Can. Current Research 2000-F2: Radiogenic Age and Isotope Studies Report 13. $11 \mathrm{p}$.

Sommer, H.; Kröner, A.; Hauzenberger, C.; Muhongo, S.; and Wingate, M. T. D. 2003. Metamorphic petrology and zircon geochronology of high-grade rocks from the central Mozambique Belt of Tanzania: crustal recycling of Archaean and Palaeozoic material during the pan-African orogeny. J. Metamorph. Petrol. 21:915934.

Stern, R. J. 1994. Arc assembly and continental collision in the Neoproterozoic East African Orogen: implications for the consolidation of Gondwanaland. Annu. Rev. Earth Planet. Sci. 22:319-351.

Stewart, J. H.; Gehrels, G. E.; Barth, A. P.; Link, P. K.; and Wrucke, C. T. 2001. Detrital zircon provenance of Mesoproterozoic to Cambrian arenites in the western United States and northwestern Mexico. Geol. Soc. Am. Bull. 113:1343-1356.

Tack, L. 1995. The Neoproterozoic Malagarazi supergroup of SE Burundi and its equivalent Bukoban Sys- tem in NW Tanzania: a current review. In Tack, L., ed. Late Proterozoic Belts in Central and Southwestern Africa. IGCP Project 302, Tervuren, Belgium, Royal Museum of Central Africa: Annales Sciences Géologiques Volume, p. 121-129.

Torsvik, T. H. 2003. The Rodinia jigsaw puzzle. Science 300:1379-1381.

Torsvik, T. H.; Ashwal, L. D.; Tucker, R. D.; and Eide, E. A. 2001. Neoproterozoic geochronology and palaeogeography of the Seychelles microcontinent: the India link. Precambrian Res. 110:47-59.

Tucker, R. D.; Ashwal, L. D.; Hamilton, M. A.; Torsvik, T. H.; and Carter, L. M. 1999a. Neoproterozoic silicic magmatism of northern Madagascar, Seychelles, and NW India: clues to Rodinia's assembly and dispersal. Geol. Soc. Am. Abstr. Program 31:A317.

Tucker, R. D.; Ashwal, L. D.; Handke, M. J.; Hamilton, M. A.; Le Grange, M.; and Rambeloson, R. A. 1999 b. $\mathrm{U}-\mathrm{Pb}$ geochronology and isotope geochemistry of the Archean and Proterozoic rocks of north-central Madagascar. J. Geol. 107:135-153.

Vavra, G. 1990. On the kinematics of zircon growth and its petrogenetic significance: a cathodoluminescence study. Contrib. Mineral. Petrol. 106:90-99.

Vavra, G.; Schmid, R.; and Gebauer, D. 1999. Internal morphology, habit and U-Th-Pb microanalysis of amphibolite-to-granulite facies zircons: geochronology of the Ivrea Zone (Southern Alps). Contrib. Mineral. Petrol. 134:380-404.

Weil, A. B.; Van der Voo, R.; Mac Niocaill, C.; and Meert, J. G. 1998. The Proterozoic supercontinent Rodinia: paleomagnetically derived reconstructions for 1100 to 800 Ma. Earth Planet. Sci. Lett. 154:13-24.

Whitehouse, M. J.; Kamber, B. S.; and Moorbath, S. 1999. Age significance of U-Th-Pb zircon data from early Archaean rocks of west Greenland: a reassessment based on combined ion-microprobe and imaging studies. Chem. Geol. 160:201-224.

Williams, I. S. 1997. U-Th-Pb geochronology by ion microprobe: not just ages, but histories. Reviews in Economic Geology 7:1-35.

Williams, I. S., and Claesson, S. 1987. Isotopic evidence for the Precambrian provenance and Caledonian metamorphism of high grade paragneisses from the Seve Nappes, Scandinavian Caledonides. II. Ion microprobe zircon U-Th-Pb. Contrib. Mineral. Petrol. 97:205-217.

Wilson, T. J.; Grunow, A. M.; and Hanson, R. E. 1997. Gondwana assembly: the view from southern Africa and East Gondwana. J. Geodynamics 23:263-286.

Yoshida, M.; Bindu, R. S.; Kagami, H.; Rajesham, T.; Santosh, M.; and Shirahata, H. 1996. Geochronologic constraints of granulite terranes of South India and their implications for the Precambrian assembly of Gondwana. J. Southeast Asian Earth Sci. 14:137-147. 